\title{
OMNES VIAE ALBAM DUCUNT. Z BADAŃ NAD POGRANICZEM POMORSKO-WIELKOPOLSKIM WE WCZESNYM ŚREDNIOWIECZU ${ }^{1}$
}

\author{
OMNES VIAE ALBAM DUCUNT. \\ STUDIES INTO THE BORDERLAND BETWEEN POMERANIA \\ AND WIELKOPOLSKA IN THE EARLY MIDDLE AGES (SYNOPSIS)
}

\begin{abstract}
The article touches upon the emergence of settlement structures in the West Pomerania Lakeland including the upper estuary of the Rega and the Parsęta as well as the Drawa and the Gwda, frequently referred to as the borderland between Pomerania and Wielkopolska. An attempt was made to assign periods to settlement developments with respect to the emergence of the borderland. Special emphasis was placed on central locations like strongholds and some islands as well as far-reaching routes leading to Białogard (Alba in Latin).
\end{abstract}

Keywords: borderland between Pomerania and Wielkopolska, West Pomerania Lakeland, settlement, early Middle Ages, strongholds, islands, bridges, treasures, routes, exchange, trade.

W pierwszej części studiów wydanych w 2008 r. obejmujących zbiór rozpraw poświęconych problematyce Pomorza Zachodniego we wczesnym średniowieczu Władysław Łosiński podjął się podsumowania dokonań badaczy zajmujących się tym zagadnieniem w 2. połowie XX i na początku XXI w. wraz z prezentacją wypracowanych $\mathrm{w}$ tych latach koncepcji (Łosiński 2008). Jedna $\mathrm{z}$ poruszonych kwestii dotyczyła zasiedlenia Pojezierza Zachodniopomorskiego pozostającego na zapleczu głównego nurtu kulturowego charakterystycznego dla pasa nadmorskiego. Rozwijając tę myśl, stwierdził wtedy: „...zgodnie ze starszymi domysłami, można wskazać na nieco inny rytm przemian osadniczych zachodzących na Pojezierzu,

\footnotetext{
* Instytut Archeologii, Uniwersytet Mikołaja Kopernika, ul. Szosa Bydgoska 44/48, 87-100 Toruń, e-mail: wojchud@umk.pl.

${ }^{1}$ Praca wykonana w ramach projektu NPRH „Człowiek na pograniczu - Systemy komunikacji interregionalnej i ich infrastruktura transferowa w północno-zachodniej części Niżu Polskiego we wczesnym średniowieczu"
} 
bardziej spowolnionych aniżeli w pasie nizin nadmorskich, gdzie wcześniej dochodziło do kształtowania się bardziej zaawansowanych form plemiennej organizacji politycznej typowej dla tzw. przełomu wczesnofeudalnego. Wydaje się, że na Pojezierzu tradycyjny zdecentralizowany model organizacji plemiennej dotrwał w postaci niewiele zmienionej do momentu włączenia Pomorza Zachodniego w granice państwa wczesnopiastowskiego" (Łosiński 2008, s. 26-27). Pogląd taki ugruntowany został zwłaszcza na podstawie wyników wcześniejszych studiów osadniczych prowadzonych zarówno przez Autora tych słów, jak i Jerzego Olczaka, który szczegółowo przeanalizował formy osadnictwa wczesnośredniowiecznego w strefie Pojezierza, zwłaszcza w jego środkowej i wschodniej części². Obaj znakomici badacze tego obszaru bazowali na tych samych wynikach wieloletnich prac terenowych, prowadzonych głównie przez Jerzego Olczaka i Kazimierza Siuchnińskiego, obejmujących zarówno systematyczną weryfikację grodzisk, jak i różne formy eksploracji wykopaliskowej i powierzchniowej stanowisk archeologicznych występujących $\mathrm{w}$ tej strefie ${ }^{3}$. Badania te stanowiły kontynuację wcześniejszych systematycznych prospekcji terenowych realizowanych na tym obszarze już od 2. połowy XIX w. zarówno przez badaczy niemieckich, jak i polskich. Pomimo, jak mogłoby się wydawać, zaawansowanego stanu badań, stopień rozpoznania tego obszaru, określanego $\mathrm{w}$ polskiej historiografii nierzadko jako pogranicze pomorsko-wielkopolskie, jeszcze do niedawna oceniany był bardzo krytycznie ${ }^{4}$. Wpływ na to miało, jak się wydaje, m.in. zaniechanie opracowań analitycznych źródeł pozyskanych w trakcie badań wykopaliskowych niektórych kluczowych stanowisk pasa pojeziernego (takich jak Bobięcino, Radacz czy Stare Drawsko), mimo wszystko dość ograniczony powierzchniowo zakres badań weryfikacyjno-sondażowych grodzisk oraz brak jak dotąd próby odwołania się do dorobku badań prowadzonych w ramach Archeologicznego Zdjęcia Polski. Nieporozumieniem było pomijanie wyników tych prac badawczych jako niewiele wnoszących do ogólnego obrazu

2 Łosiński 1982; Olczak 1991, s. 11; w tej publikacji uzasadnienie zakresu przestrzennego studiów, które „ze względu na odległe i marginalne położenie w stosunku do zasadniczych ugrupowań osadniczych Pojezierza Zachodniopomorskiego" nie obejmowały jego zachodniej części, tj. mezoregionu Pojezierza Myśliborskiego i Choszczeńskiego.

3 Badania archeologiczne omawianej części Pojezierza Zachodniopomorskiego mają długą historię sięgającą co najmniej 2. połowy XIX wieku. Stan badań nad osadnictwem wczesnego średniowiecza najpełniej omówił W. Łosiński (1982, s. 12-17), podkreślając wysiłek zwłaszcza niemieckich badaczy na polu rejestracji stanowisk z tego okresu. Na uwagę zasługuje przede wszystkim stworzenie długiej listy grodzisk pomorskich, która w zasadniczym zrębie nie zmieniła się do lat 60 . XX wieku (por. również Kasiski 1869; 1874; Behla 1888; Łęga 1930; Kunkel 1932; Eggers 1960; Stafiński 1960; Wilke 1963). Przełomowe znaczenie miały badania weryfikacyjno-sondażowe prowadzone w latach 60. przez Katedrę Archeologii Polski i Powszechnej UAM w Poznaniu (Olczak, Siuchniński 1966, 1968, 1970; Łosiński, Olczak i Siuchniński 1971). W tym samym okresie badaniami wykopaliskowymi objęto oba grodziska w Radaczu (Siuchniński 1962, 1964) oraz grodzisko i zamek w Starym Drawsku (Janocha 1964, 1967).

4 Na temat niedostatecznego stanu rozpoznania Pojezierza por. Piskorski 2002, s. 172; również Lachowicz, Olczak i Siuchniński 1977, s. 9; Olczak 1991, s. 13, przypis 18. . 


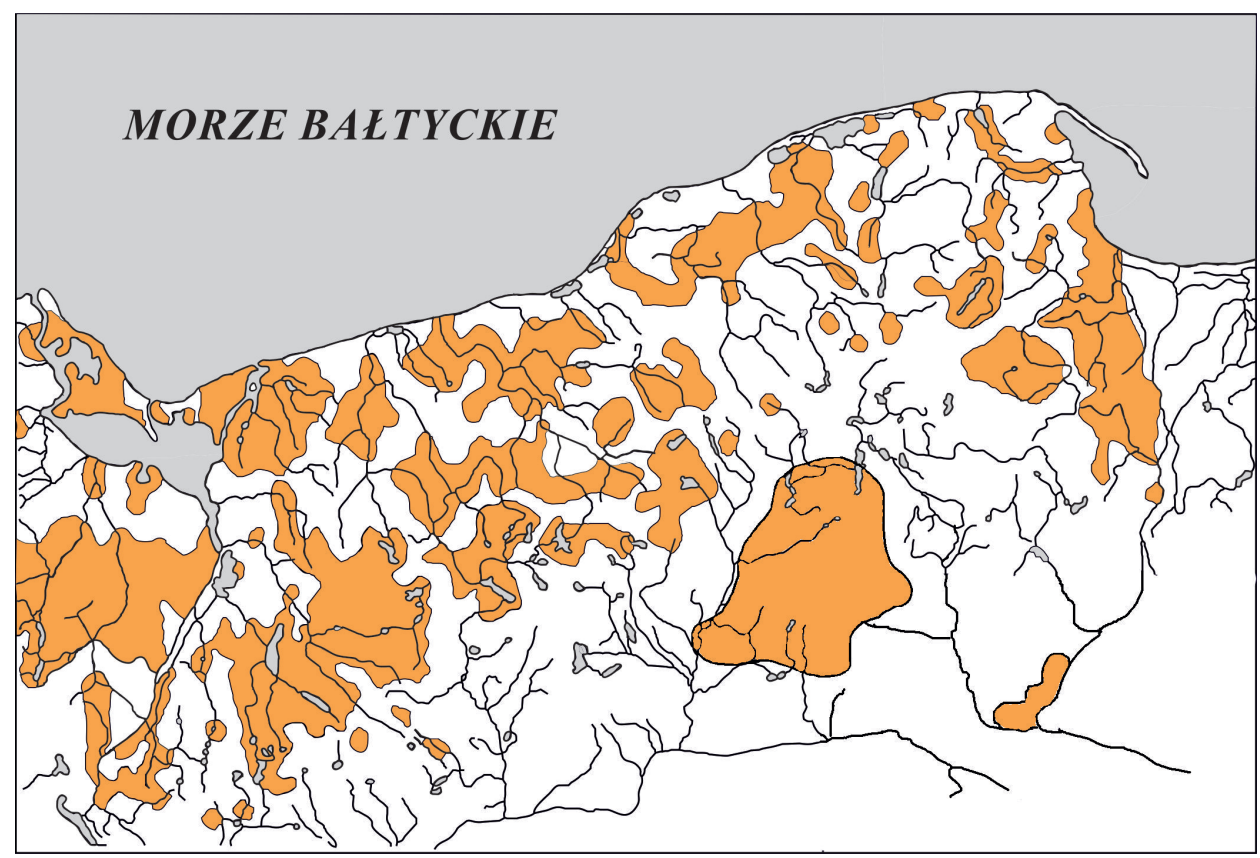

Ryc. 1. Sytuacja osadnicza na Pomorzu w X w. z zaznaczonymi terytoriami osadniczymi omawianymi w niniejszym artykule (wg Losińskiego 1982)

osadnictwa omawianego obszaru. Konsekwencję takiego stanu rzeczy widać zwłaszcza w niektórych pracach mediewistów bazujących z konieczności na efektach weryfikacji archeologicznej sprzed niemal pół wieku ${ }^{5}$.

W ostatnich kilkunastu latach zintensyfikowano badania Pojezierza Zachodniopomorskiego, zwłaszcza jego części środkowej obejmującej całe Pojezierze Drawskie, północną część Pojezierza Szczecinieckiego i zachodnią część Pojezierza Bytowskiego, czyli tereny od górnej zlewni Regi i kolana środkowej Drawy po zlewnię górnej Radwi i górnej Gwdy (ryc. 1). Badania prowadzone na tym obszarze przez ośrodek toruński w ramach kilku projektów badawczych przyniosły wiele nowych źródeł archeologicznych stanowiących wystarczającą przesłankę, aby jeszcze raz przyjrzeć się niektórym kwestiom dotyczącym rozwoju osadnictwa na tym terenie i kształtowania się różnych form organizacji społeczno-politycznych, również pod kątem ich pewnej specyfiki zauważonej przez W. Łosińskiego. Z tej perspektywy patrząc, momentem przełomowym było podjęcie w 2003 r. prac badawczych na nowo odkrytym stanowisku w Żółtym nad Jeziorem Zarańskim

5 Por. Wielgosz 2006; Rymar 2015 - w tym przypadku podkreślić należy wartość kwerendy literatury przeprowadzonej przez tego badacza i uwzględnienie wielu ,zapomnianych" przez archeologów informacji z XIX i początku XX wieku. 
(stan. 33) zinterpretowanym jako multifunkcyjne miejsce związane pierwotnie ze sferą mityczno-sakralną (Chudziak 2009). Zlokalizowane ono zostało na niewielkiej wyspie bezpośrednio przy półwyspie, w którego obrębie znane było grodzisko datowane we wcześniejszej literaturze na IX-XII wiek (Olczak, Siuchniński 1966, s. 77-78). Badania całego zespołu osadniczego, a zwłaszcza wyspy prowadzone były w ramach dwóch projektów „Wczesnośredniowieczne miejsca kultu przy śródlądowych akwenach jeziornych na Pomorzy Środkowym” (KBN) i „Wyspa w Żółtym na przełomie I i II tysiąclecia - centrum społeczno-kulturowe na Pomorzu zachodnim” $(\mathrm{NCN})^{6}$. Kontynuacją tych prac jest projekt NPRH „Człowiek na pograniczu - Systemy komunikacji interregionalnej i ich infrastruktura transferowa w północno-zachodniej części Niżu Polskiego we wczesnym średniowieczu", który umożliwił kompleksowe przebadanie kilku innych wczesnośredniowiecznych ośrodków osadniczych w strefie Pojezierza Zachodniopomorskiego oraz analizę wielu wcześniejszych niepublikowanych materiałów źródłowych (Nętno, Stare Borne, Bobięcino, Parsęcko, Radacz). Kluczowe znaczenie w rozpoznaniu osadnictwa tego regionu miał również projekt NPRH „Atlas grodzisk wczesnośredniowiecznych Polski", w którego ramach przeprowadzono akcję weryfikacyjną chronologii, funkcji i układu przestrzennego obiektów obronnych w obecnym powiecie drawskim, obejmującą ich rozpoznanie metodą wierceniowo-sondażową i geomagnetyczną ${ }^{7}$ Szczególnie istotne okazało się wykorzystanie danych lidarowych, w wyniku czego odkryto kilka nowych grodzisk i cmentarzysk kurhanowych o metryce wczesnośredniowiecznej ${ }^{8}$. Rozpoznanie omawianego terytorium uzupełniały penetracje podwodne zainicjowane na Jeziorze Gągnowskim przy wyspie w Nętnie (stan. 1), a następnie realizowane w kolejnych edycjach programu konserwatorsko-archeologicznego „Ewidencja stanowisk podwodnych AZP” finansowanych przez Narodowy Instytut Dziedzictwa w latach 2006-2009 (Nętno, stan. 38; Żółte,

${ }^{6}$ Autorami obu projektów był W. Chudziak i R. Kaźmierczak, przy znaczącym wkładzie koncepcyjnym J. Niegowskiego; por. Chudziak, Kaźmierczak 2014, 2017; w obu publikacjach wcześniejsza literatura. Badania zespołu osadniczego w Żółtym prowadzone zarówno na lądzie, jak i pod wodą realizowane były przez zespół interdyscyplinarny złożony z archeologów, geomorfologów, hydrografów, archeozoologów, palinologa, archeobotaników, dendrochronologów i historyka; por. również ogólne omówienie zastosowanej strategii badawczej, Kulesza 2015.

7 W sumie 15 grodzisk badanych w latach 2015-2017: Donatowo, Drawsko Pomorskie, Gudowo, Kalisz Pomorski, Kołomąt, Lubieszewo, Mielenko Drawskie, Nętno, Oleszno, Rusinowo, Siemczyno I i II, Stare Drawsko, Suliszewo, Żołędowo; P. Błędowski, J. Bojarski, W. Chudziak, R. Kaźmierczak, M. Weinkauf, $Z$ badań weryfikacyjnych wczesnośredniowiecznych grodzisk Pojezierza Drawskiego (w druku); ponadto badania geomagnetyczne na niektórych z tych grodzisk przeprowadził Piotr Wroniecki (Źółte, stan. 1; Mielenko Drawskie, stan. 1; Drawsko Pomorskie, stan. 1; Suliszewy, stan. 1).

${ }^{8}$ Analizy przeprowadził J. Niegowski, który wytypował miejsca do weryfikacji terenowej. Dane te przeanalizował również A. Kuczkowski z Muzeum w Koszalinie, który opublikował informację o odkryciu tych grodzisk bez należytej weryfikacji terenowej (2017, s. 197-204; tam błędne wskazania lokalizacyjne (grodzisko w Siemczynie nad Zatoką Henrykowską Jeziora Drawskiego znajduje się w innym miejscu) oraz niewłaściwe przyporządkowanie administracyjne (grodzisko w Siemczynie nad jeziorem Wilczkowo określono jako Borkowo, grodzisko w Złocieńcu jako Budowo będące obecnie częścią tego miasta). 


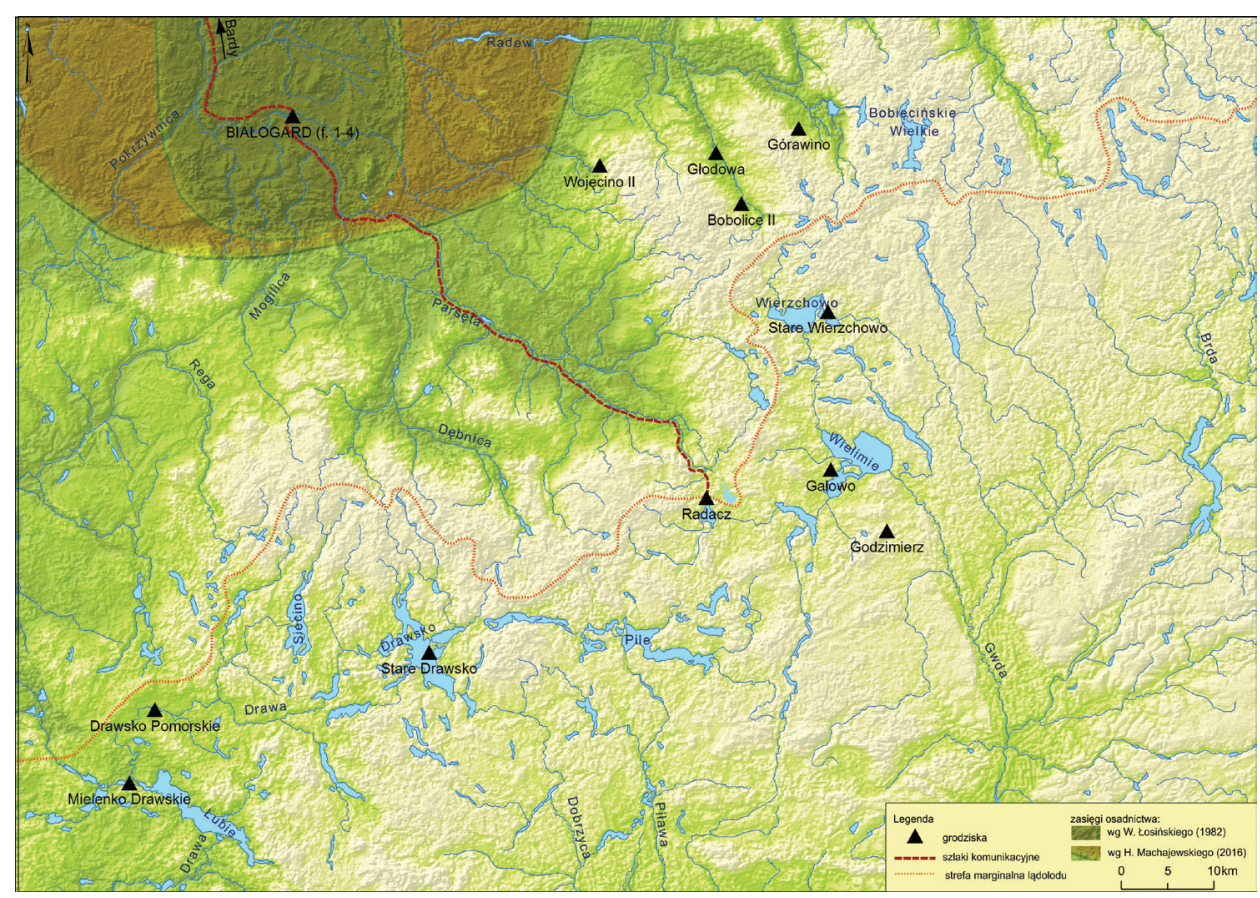

Ryc. 2. Struktury osadnicze w środkowej części Pojezierza Zachodniopomorskiego (Pojezierze Drawskie, Pojezierze Szczecinieckie, Pojezierze Bytowskie) w 2. połowie VII-VIII wieku

stan. 33; Żydowo, stan. 42 i 43; Radacz, stan. 74; Jamienko, stan. 9; Bobięcino, stan. 3) oraz 2011-2015 (Drawsko Pomorskie, stan. 105; Nętno, stan. 38, Żydowo, stan. 44), również przy okazji badań prowadzonych w ramach wspomnianych wcześniej projektów badawczych (Kola, Wilke 2004, s. 545-551; Kaźmierczak, Niegowski i Ważny 2006, 455-463; Szulta 2007; 2008, s. 152-155; Radka, 2010, s. 205-222; Chudziak, Kaźmierczak i Niegowski 2011; s. 131-140; 2016, s. 145-161). Badania te nawiązywały w dużej mierze do prospekcji prowadzonych przez ośrodek toruńskiej archeologii podwodnej jeszcze w latach 80. ubiegłego wieku w ramach systematycznych prac wykopaliskowych na wyspach Jeziora Bobięcińskiego oraz zmeliorowanego w XIX w. akwenu w Parsęcku (Kola, Wilke 2006, s. 151-173, tam wcześniejsza literatura dotycząca mostu w Bobięcinie; Gackowski, Jabłoński 1993, s. 115-133; Gackowski 1993; por. również Łosiński 2008, s. 27).

Znaczenia zreferowanych tu pokrótce badań realizowanych w XXI w. nie można przecenić, gdyż to dzięki nim uzyskano cały zestaw nowych informacji źródłowych dotyczących aspektu funkcjonalno-przestrzennego kształtowania się struktur osadniczych Pojezierza, a przede wszystkim ich chronologii bezwzględnej. W tym przypadku bezcenne okazały się wyniki analiz dendrochronologicznych. W sumie metodą tą uściślono datowanie dziesięciu stanowisk archeologicznych Pojezierza, 
uzyskując ponad 150 oznaczeń dendrochronologicznych, co w skali całego interioru Pomorza sprawia, że obszar ten należy obecnie do najlepiej rozpoznanych pod tym względem9. Największą serię datowań pozyskano dla drewnianych konstrukcji nadbrzeżnych, pomostów i mostu odkrytych wokół wyspy w Żółtym na Jeziorze Zarańskim (57 oznaczeń zawierających się w dwóch przedziałach czasu AD 886-900 tpq oraz AD 1041-1082) oraz mostu i pomostów zarejestrowanych przy wyspie w Nętnie na Jeziorze Gągnowskim (w sumie 40 oznaczeń - AD 948-976 i 1040). Dużą serię oznaczeń pozyskano również dla mostu w Radaczu (25 dat - AD 858/74971), mostu i drogi ze Starego Bornego/Żydowa (15 dat - AD 910, 937-956), mostu w Bobięcinie (7 dat - AD 1016/17, 1024 oraz 1080-1082/83; 6 dat AD 1100, 1139-1167). Te ostatnie były szczególnie istotne wobec wcześniejszych datowań tej przeprawy opublikowanych jeszcze w latach 80. wskazujących jedynie na młodszą jej metrykę (Wilke 1985; AD 1142-1185). Pojedyncze oznaczenie uzyskano natomiast dla reliktów drewnianych mostów w Rakowie (AD 1178), Parsęcku (AD 1058, 1072) i Świeszynie (1036-1058/1059), a także przeprawy na Drawie w Drawsku Pomorskim (AD 1159 tpq, 1205 tpq) oraz bliżej nieokreślonych pod względem funkcji pali przy wyspie w Suliborzu (AD 1178 ?). Do oceny chronologii niektórych stanowisk wykorzystano również datowanie radiowęglowe, niezbędne zwłaszcza $\mathrm{w}$ przypadku niektórych kategorii znalezisk, takich jak zwęglone relikty wału i zabudowy grodowej (Donatowo, stan. 1; Drawsko Pomorskie, stan. 1; Lubieszewo, stan. 1; Mielenko Drawskie, stan. 1; Nętno, stan. 1; Oleszno, stan. 1; Siemczyno, stan. 1, Suliszewo, stan. 1), kości zwierzęce (Żółte, stan. 33, dwa szkielety koni; Nętno, stan. 38, czaszka konia) czy dłubanki (Nętno, stan. 1; Żółte, stan. 33). Szeroki zakres ich wykorzystania, przy równoczesnym zaawansowaniu analiz typologiczno-porównawczych ruchomego materiału źródłowego, zwłaszcza ceramiki naczyniowej i stosunkowo licznych znalezisk numizmatycznych, umożliwia podjęcie analiz przestrzenno-funkcjonalnych struktur osadniczych zarówno w aspekcie diachronicznym, jak i synchronicznym. Istotnym elementem prowadzonych prac były również badania przyrodnicze umożliwiające rekonstrukcję warunków środowiskowych oraz określonych sektorów życia społeczno-gospodarczego ${ }^{10}$.

Przypomnijmy zatem, że w środkowej części Pojezierza Zachodniopomorskiego obejmującego strefę głównego wododziału rozgraniczającego Przymorze i zlewnię Warty i Noteci, W. Łosiński wyróżnił pięć ugrupowań osadniczych identyfikowa-

${ }^{9}$ Badania dendrochronologiczne przeprowadził prof. Tomasz Ważny (Bobięcino, stan. 3; Nętno, stan. 38; Parsęcko, Radacz, stan. 74; Rakowo, stan. 18; Żółte, stan. 33, Żydowo, stan. 42), jak również prof. Marek Krąpiec (Bobięcino, stan. 3; Drawsko Pomorskie, stan. 105); Chudziak, Kaźmierczak, Niegowski i Ważny 2009, s. 99-131.

${ }^{10}$ Badania takie w największym zakresie przeprowadzono dla wyspy w Żółtym na Jeziorze Zarańskim oraz sąsiedniego centrum osadniczego w Nętnie na Jeziorze Gągnowskim. Jak dotąd opublikowano wyniki prac prowadzonych na pierwszym wymienionym stanowisku (Chudziak, Kaźmierczak 2014). Uwzględniono w nich m.in. problem rekonstrukcji poziomów wód powierzchniowych dla okresu wczesnego średniowiecza, co dla strefy Pojeziernej wydaje się punktem wyjścia wszelkich analiz osadniczych. 


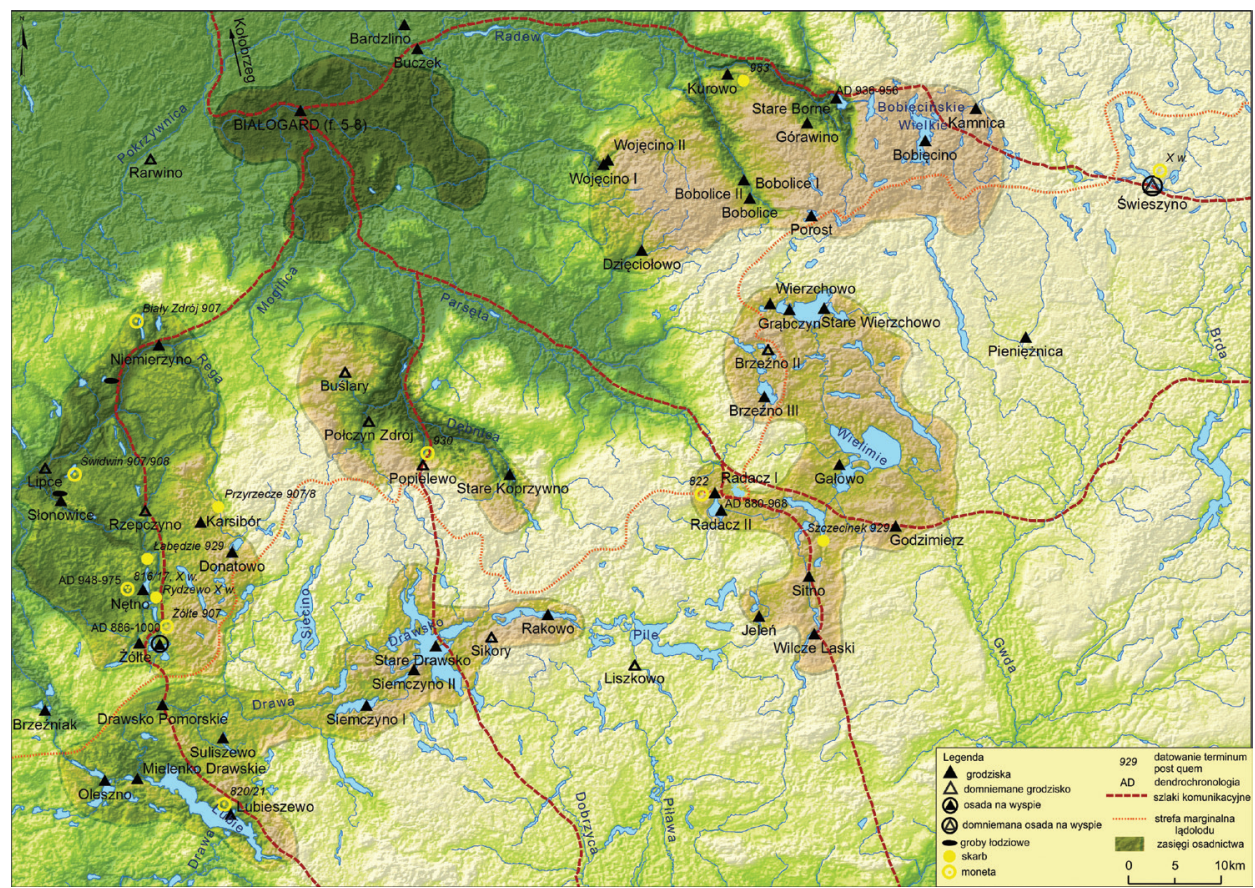

Ryc. 3. Struktury osadnicze w środkowej części Pojezierza Zachodniopomorskiego (Pojezierze Drawskie, Pojezierze Szczecinieckie, Pojezierze Bytowskie) w IX-X wieku

nych ze wspólnotami wyższego rzędu, które z reguły określane są w literaturze przedmiotu terminem „plemię” (gens), a ostatnio również „struktura wodzowska” (chiefdom). Są to: a) południowo-wschodnia część ugrupowania łobeskiego, zajmująca tereny zlewni Dębnicy, prawego dopływu Parsęty aż po jej źródła, b) ugrupowanie bobolickie nad górną Radwią, c) ugrupowanie szczecinieckie nad górną Gwdą, powiązane z górnoparsęckim, d) ugrupowanie wokół Jeziora Drawskiego, Komorza i Piły, oraz e) ugrupowanie górnodrawskie zajmujące również tereny nad górną Regą, ryc. 1. Ich genezę odnosił jeszcze do VII-VIII w., łącząc te obszary razem z terytorium nad dolną Regą i dolną oraz środkową Parsętą, w jeden domniemany organizm wielkoplemienny charakteryzujący się dominacją grodów o dużej i średniej powierzchni wnętrza (Losiński 1982, s. 197). W IX w., a zwłaszcza w 2. połowie tego stulecia miało dojść na tych terenach do istotnych przekształceń osadniczych, utrwalonych w kolejnym stuleciu, polegających na wykształceniu się w ramach wymienionych regionów dwuszczeblowej organizacji terytorialnej złożonej z kilku (2-8) małych lokalnych wspólnot niższego szczebla typu opolnego z czołami przeważnie w formie grodu i kilku satelickich osad wiejskich. Szczegółowa analiza struktur osadniczych w rejonie jezior Wierzchowo i Wielimie skłoniła W. Łosińskiego również do opinii o istnieniu w tym samym czasie mniejszych 
jednostek osadniczych typu pola. Generalnie tereny te według tego badacza pozbawione były naczelnego grodu plemiennego. Rozwinąć się na nich miał „organizm polityczny o dość archaicznych formach ustrojowych", zwłaszcza w porównaniu z terytorium dolnoparsęckim zdominowanym wcześniej przez gród w Bardach, a w późniejszym okresie przez ośrodek wczesnomiejski w Kołobrzegu ${ }^{11}$. Struktury te według badacza uległy likwidacji w końcu X w. w związku z umacnianiem się na Pomorzu władztwa pierwszych Piastów.

Wyniki analiz osadniczych przeprowadzonych przez W. Losińskiego były na tym etapie studiów nad osadnictwem wczesnośredniowiecznym Pojezierza Zachodniopomorskiego bezcenne, m.in. z punktu widzenia przyporządkowania etnokulturowego i politycznego tych ziem. Wynikało z nich, że strefa przebiegu głównego wododziału pomorskiego obejmowała w okresie plemiennym zintegrowane przestrzennie osadnictwo rozwijające się po obu jego stronach (IX-X w.). Na obszarze tym koncentrowały się bowiem bezpośrednio sąsiadujące ze sobą wspólnoty terytorialne zajmujące zlewnie głównych rzek pomorskich, spływających w stronę Bałtyku, tj. Regi i Parsęty wraz z Radwią oraz Drawy i Gwdy wraz z Piławą stanowiących dopływy Noteci. Spostrzeżenia te były istotne zwłaszcza w kontekście ustaleń mediewistów spierających się na temat przebiegu pierwotnej granicy pomiędzy plemionami pomorskimi i wielkopolskimi, choć jak wiadomo podstawę źródłową tej dyskusji stanowiły głównie o wiele późniejsze przekazy pisane (XII-XIII wiek). W ocenie niektórych z nich, przede wszystkim Kazimierza Ślaskiego i Zbigniewa Wielgosza, tereny Pojezierza obejmujące lesisty grzbiet moreny czołowej miały stanowić pierwotne pogranicze obu tych regionów (Ślaski 1954, s. 91-109; 1972; Wielgosz 2006, s. 47; Rymar 2015, s. 120). Rozdzielała je strefa puszczy stanowiącej „straszne i bardzo rozległe pustkowie” (nemus horrendum et vastum), zanotowane w kontekście opisu drogi powrotnej orszaku misyjnego biskupa Ottona z Bambergu w 1124 r. zmierzającego w stronę ośrodka miejskiego w Ujściu nad Notecią położonego, jak to ujęto w Żywocie z Prüfening, ,na samej granicy" państwa Piastów (Rosik 2010, s. 200; Rymar 2015, s. 118). Sceptycznie do tej koncepcji kształtowania się pogranicza pomorsko-wielkopolskiego podchodzili natomiast Józef Spors i Edward Rymar, którzy optowali za pierwotną granicą opartą na linii Noteci i Warty (Spors 1986, s. 1-29, Rymar 1988; 2015, s. 118, por. Piskorski 2002, s. 56). Szczegółowo omówił ten problem zwłaszcza drugi z tych badaczy, zwracając uwagę, że bliżej strefy pasma moren czołowych granicę państwa Piastów przesunął dopiero Władysław Laskonogi (Rymar 1988, s. 367, 2017, s. 32-41). Wtedy dopiero górna Drawa miała stać się rzeką graniczną, rozdzielającą dzierżawy książąt pomorskich od władztwa wielkopolskiego ${ }^{12}$. Nieco

${ }^{11} \mathrm{O}$ dominującej roli grodu w Bardach w okresie od VIII/IX do schyłku IX w. reprezentującego horyzont grodów przypominających warownię w Feldbergu, por. Łosiński 2008, s. 63-79.

12 Świadczyć miałyby o tym przede wszystkim uposażenia Władysława Odonica dla cystersów w Lubiążu w okolicach jezior Lubie i Bytyń (1234) oraz księcia pomorskiego Warcisława III dla klasztoru w Białobokach w okolicach Drawska Pomorskiego (pustkowie „Sarcthicze”, puszcza zarań- 


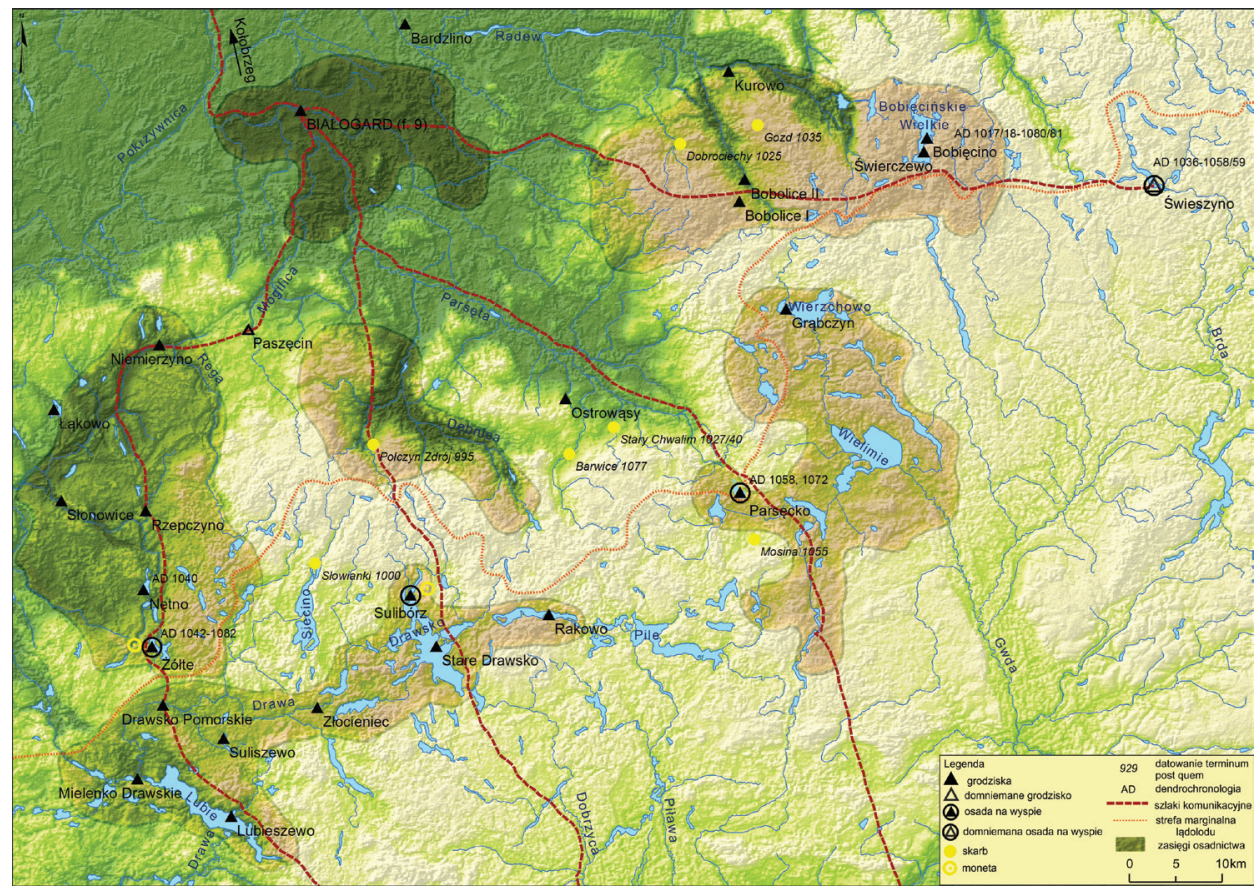

Ryc. 4. Struktury osadnicze w środkowej części Pojezierza Zachodniopomorskiego (Pojezierze Drawskie, Pojezierze Szczecinieckie, Pojezierze Bytowskie) w XI wieku

inny pogląd wyraził Henryk Łowmiański, widząc w strefie puszczańskiej „rubieżne pustkowie, świadczące raczej o odseparowaniu Pomorza od śródlądowych plemion lechickich” (Łowmiański 1973, s. 370-373). Według Z. Wielgosza „wiele argumentów przemawia za tym, iż rozpatrywany tu obszar dość długo zachował charakter strefy pogranicznej, tzn. obszaru przenikania i krzyżowania się prądów osadniczych, również politycznych z północy od strony Pomorza, zwłaszcza zaś z południa od strony Wielkopolski, i to zarówno w dobie plemiennej, jak i w okresie wczesnopaństwowym" (2006a, s. 307).

Problem kształtowania się pogranicza pomorsko-wielkopolskiego przykuwał również wielokrotnie uwagę archeologów. Większość z nich zajmowała się jednak kwestią granicy na linii Noteci i Warty, zwłaszcza w kontekście studiów nad początkiem państwa wczesnopiastowskiego i genezą grodów nadnoteckich (Leciejewicz 1957; Naumowiczówna 1963; Kurnatowska 2000; Kara 2009; Wyrwa 2004, 2007; Brzostowicz 2007). Zdecydowanie rzadziej poruszany był natomiast problem kształtowania się pogranicza pomorsko-wielkopolskiego w strefie Pojezierza Za-

ska - 1254). Tak wyglądać miała również granica południowo-wschodnich ziem wchodzących w skład diecezji pomorskiej w XII i 1 połowie XIII wieku (Rębkowski 2007, s. 16). 
chodniopomorskiego (m.in. Janocha, Lachowicz i Ptaszyńska 1972, s. 29; Wilke 1963, s. 176; Łosiński 1982, s. 12). Ostatnio zagadnienie to podjęto w związku z wynikami badań archeologicznych przeprowadzonych na wyspie i pobliskim grodzisku w Żółtym na Jeziorze Zarańskim (stanowisko 33) i na położonym również na wyspie grodzisku w Nętnie nad Jeziorem Gęgnowskim (stanowisko 1). Pozostałości obu ośrodków osadniczych, oddalonych od siebie w linii prostej zaledwie o $5 \mathrm{~km}$, znajdują się w zlewni górnej Regi zajmowanej przez jedną ze wspólnot plemiennych wyróżnionych na Pojezierzu przez W. Łosińskiego (Chudziak, Siemianowska i Kaźmierczak 2014; Chudziak, Siemianowska 2016). Zarówno ośrodek w Żółtym, jak i w Nętnie usytuowany był bezpośrednio przy wiodącym z Wielkopolski w kierunku Białogardu i Kołobrzegu szlaku dalekosiężnym odzwierciedlonym na omawianym odcinku w znaleziskach skarbów/monet i w układzie przestrzennym struktur osadniczych.

Warto w tym miejscu przypomnieć niektóre szczegóły tych ustaleń. W obrębie niewielkiej (0,25 ha) wyspy na Jeziorze Zarańskim usytuowanej u źródeł Starej Regi, blisko głównego wododziału pomorskiego, odsłonięto relikty drewnianych umocnień nadbrzeżnych w postaci palisady i dookolnych rusztów datowanych metodą dendrochronologiczną na lata 886-890 oraz 900 (tpq), związane z nimi kamienne bruki pokrywające większą część wyspy, a ponadto duży, ponadprzeciętnej wielkości granitoid pierwotnie zajmujący $\mathrm{w}$ obrębie wyspy zapewne wyeksponowane miejsce. Całość nawiązywała w formie do występujących na wyspach brytyjskich w tym samym okresie tzw. crannogów, sztucznych wysp stanowiących ważne ogniwa tamtejszej struktury przestrzennej osadnictwa (por. Menotti 2012, s. 143; tam literatura). Według dotychczasowych interpretacji miejsce to, usytuowane $\mathrm{w}$ bezpośrednim sąsiedztwie synchronizowanego $\mathrm{z}$ nim grodu $(0,33$ ha powierzchni wnętrza), pod koniec IX i co najmniej $\mathrm{w} 1$. połowie $\mathrm{X}$ w. pełniło złożone funkcje społeczno-kulturowe związane głównie z wymianą i kultem (m.in. odkryto srebrną drachmę z VII-VIII w., brązowe okucie w formie stylizowanej głowy zwierzęcej, liczne kości zwierzęce i fragmenty naczyń ceramicznych reprezentujących przede wszystkim typ Menkendorf). Ze względu na charakterystyczne położenie oraz organizację przestrzeni ośrodek w Żółtym uznano za ważny węzeł komunikacyjny i „bramę” w kierunku Wielkopolski (Chudziak, Siemianowska 2017, s. 297; Chudziak, Kaźmierczak 2017).

Młodszy od niego był natomiast niewielki ( 0,36 ha) gród w Nętnie datowany zasadniczo na 1. połowę X w., połączony w $948 \mathrm{r}$. z brzegiem jeziora drewnianym mostem (stanowisko 38) (Szulta 2007; Chudziak, Kaźmierczak i Niegowski 2015). Druga faza jego użytkowania związana $\mathrm{z}$ jego naprawą pokrywa się z okresem budowy mostu na Ostrowie Lednickim (lata 963-964, a następnie 969-975 rok). W obrębie reliktów przeprawy odkryto liczne przedmioty luksusowe świadczące o znaczącej pozycji tego ośrodka (m.in. zdobiony grot włóczni o bogatej ideografii chrześcijańskiej, trzewik pochwy miecza, miniaturowy toporek, pięć żeleźców toporów, szalki do wagi, wędzidło, podkowę i inne; Kaźmierczak, Niegowski 
i Ważny 2006; Chudziak 2006; Chudziak, Kaźmierczak i Niegowski 2016, s. 145-186). Obraz ten uzupełnia znalezisko trzech fragmentów dirhamów pochodzących z warstw kulturowych grodziska (dwóch z 816/817, jeden z X w.) ) $^{13}$, a ponadto zdeponowane w pobliżu Jeziora Gągnowskiego dwa skarby monet arabskich (Łabędzie II, tpq 929 r. i Rydzewo, X w.; Horoszko i in. 2016). Zarówno na wyspie, jak i wokół niej na dnie jeziora dominowały naczynia typu Menkendorf z pojedynczymi okazami garnków typu Sukov i Vipperow. Kontekst przyrodniczo-kulturowy tych odkryć i ich chronologia, przypominające model wielkopolskiego Ostrowa Lednickiego (wyspa, gród, most, militaria) skłania do interpretacji omawianego ośrodka jako przyczółku władzy piastowskiej na drodze w kierunku Bałtyku. Traktować go również można jako „następcę” zniszczonego lub opuszczonego ośrodka w Żółtym, którego rola wzrosła kosztem tego ostatniego wraz z podporządkowaniem przez władców wielkopolskich Pomorza Środkowego z grodem kołobrzeskim na czele. Ze względu na brak oznaczeń dendrochronologicznych elementów konstrukcyjnych mostu późniejszych niż 975 r., świadczących o jego kolejnej naprawie, można sądzić, że jego zniszczenie nastąpiło jeszcze przed końcem X w., co synchronizować należy z horyzontem czasowym kresu funkcjonowania wielu grodów pomorskich, spowodowanym zapewne ekspansją piastowską. Nie jest to jednak jedyna możliwa wersja wydarzeń, gdyż zarówno most, jak i gród w Nętnie mogły równie dobrze zostać zniszczone trochę później, tj. w 1. ćwierci XI w. w związku z działaniami militarnymi prowadzącymi do uniezależnienia się tej części Pomorza od Piastów. Na podstawie datowań dendrochronologicznych można tylko domyślać się, że przeprawa mostowa $\mathrm{w}$ tym miejscu została ponownie odbudowana dopiero w $1040 \mathrm{r}$. w zupełnie innych realiach społeczno-politycznych, choć brak jest jakichkolwiek śladów użytkowania pobliskiego grodu pochodzących z tego okresu.

W latach 40. XI w. doszło natomiast do odbudowy „starego” ośrodka plemiennego w Żółtym, który tym razem prosperował co najmniej przez kolejne cztery dekady (lata 1042-1082). Na okres ten przypada całkowita dominacja naczyń typu Vipperow i Teterow (Chudziak, Kaźmierczak 2014, s. 19-20). Kontekst kulturowy odkryć związanych z drugą fazą użytkowania wyspy na Jeziorze Zarańskim i rodzaj znalezisk wskazują, że podobnie jak w okresie wcześniejszym, miejsce to odgrywało istotną rolę w sferze wymiany i sacrum (targ i miejsce kultu). Liczne utensylia kupieckie, takie jak monety, liczne odważniki kupieckie i wagi, a ponadto militaria, przedmioty związane z przędzalnictwem i tkactwem czy biżuteria, zalegające zarówno na wyspie, jak i pod wodą w jej najbliższym otoczeniu świadczą o centralnych funkcjach tego miejsca i przebywaniu tu elit społecznych. Wydaje się, że część przedmiotów była celowo zatopiona, co wobec licznych depozytów zwierzęcych i roślinnych znalezionych również na dnie otaczającego wyspę akwe-

${ }^{13}$ Analizę numizmatyczną dirhamów z Nętna wykonała Dorota Malarczyk z Muzeum Narodowego w Krakowie. 
nu oraz charakterystycznej zabudowy wskazywać może na waloryzowanie tego pogranicznego miejsca również w kategoriach mityczno-sakralnych.

Relacja przestrzenno-chronologiczna obu omówionych ośrodków osadniczych skłania do wniosku, że pierwszą fazę użytkowania wyspy w Żółtym i być może początkowy etap istnienia grodu w Nętnie powiązać należałoby $\mathrm{z}$ tradycyjnymi strukturami osadniczymi wykształconymi w dorzeczu dolnej Regi 2. połowie IX i w X w., tworzącymi zapewne jedną dużą wspólnotę terytorialną o powierzchni około $700 \mathrm{~km}^{2}$ (grodziska w Donatowie, Słonowicach, Karsiborze, Niemierzynie, Rzepczynie, Łąkowie i Lipcach). Znamienne, że obszar ten obfituje w liczne znaleziska dirhamów arabskich występujących zarówno w skarbach, jak i w formie pojedynczych monet, co wskazywałoby na ożywione dalekosiężne kontakty handlowe mieszkańców tego regionu zwłaszcza w pierwszych trzech dekadach $\mathrm{X}$ w., czyli $\mathrm{w}$ okresie przypadającym na pierwszą fazę funkcjonowania centrum osadniczego na wyspie Jeziora Zarańskiego. W sumie z terenów tych znanych jest obecnie osiem tego rodzaju stanowisk, co stanowi wyjątkowe jak na warunki całego Pojezierza ich skupienie (wymienione wcześniej skarby w Łabędziach po $929 \mathrm{r}$. i Rydzewie X w., skarb w Przyrzeczu, po 890 r. oraz pojedyncze znaleziska monetarne: Biały Zdrój, 907/908; Świdwin/Słonowice, 907/908; Żółte 1, 907/908; Żółte 33, VII-VIII wiek; Nętno, IX-X wiek). Być może znamienne jest usytuowanie $\mathrm{w}$ tej strefie również grobów z obstawą kamienną w kształcie łodzi, niewykluczone, że powiązanych z tą fazą osadnictwa (Chudziak, Siemianowska 2014, s. 431). Natomiast drugą fazę użytkowania wyspy w Żółtym - biorąc pod uwagę kontekst historyczny i geografię środkowopomorskiego ówczesnego osadnictwa - wiązać należy $\mathrm{z}$ istnieniem $\mathrm{w}$ tym miejscu ośrodka wyznaczającego południową granicę księstwa zachodniopomorskiego, niewykluczone, że władanego w tym okresie przez wymienionego przez Roczniki Altajskie pod rokiem 1046 Zemuzila (Chudziak, Siemianowska 2016, s. 189; por. również Śliwiński 2000, s. 18, tam literatura). W okresie tym nie istnieje już większość grodów wchodzących w skład rozwiniętej wcześniej na tym terenie wspólnoty terytorialnej, zniszczonych zapewne jeszcze w trakcie ekspansji piastowskiej lub dopiero na etapie reakcji Pomorzan w 1 tercji XI wieku (Nętno).

Inaczej kształtowała się natomiast sytuacja bezpośrednio na południowy wschód od głównego wododziału pomorskiego, gdzie brak jest udokumentowanych pozostałości ośrodków nawiązujących rangą do centrów osadniczych w Żółtym i Nętnie. $\mathrm{Z}$ analizy struktur przestrzennych osadnictwa wynika jednak, że na obszarze tym szczególne znaczenie posiadał stosunkowo duży (0,5 ha?) gród w Drawsku Pomorskim leżący nad Drawą, bezpośrednio przy przeprawie przez tę rzekę. Geneza grodu drawskiego sięga zapewne VIII w., o czym świadczyć mogą zespoły ceramiki reprezentowanej przez naczynia typu Sukow i Feldberg. Razem z pobliską warownią w Mielenku Drawskim stanowiły one najstarszy horyzont budownictwa obronnego w tej części Pojezierza (Dulinicz 2001). Z grodziskami w Lubieszewie, Suliszewie i Olesznie datowanymi na IX-X w. stworzyły one z czasem strukturę 
wyraźnie wyodrębniającej się w tej części zlewni Drawy wspólnoty terytorialnej o powierzchni około $300 \mathrm{~km}^{2}$, wyróżnionej również przez W. Łosińskiego (razem z regionem obejmującym dorzecze górnej Regi). Lokalizacja grodu drawskiego, bezpośrednio przy przeprawie przez rzekę i jego położenie w jednym układzie liniowym z ośrodkami w Żółtym i Nętnie, a dalej na południe z grodem w Lubieszewie nad jeziorem Lubie wskazuje na istnienie w tym miejscu w IX-X w. traktu komunikacyjnego przechodzącego przez główny wododział Pomorza i łączącego Przymorze z leżącą w głębi interioru Wielkopolską. Co najmniej od połowy X w. trakt ten wiódł przez nadnotecki gród w Wieleniu (Wyrwa 2007, s. 294). Jeżeli przyjmiemy, że pojedyncze znaleziska monet - podobnie jak intencjonalne depozyty zbiorowe (skarby) - stanowić mogą świadectwo przebiegu osi komunikacyjnych, to odkrycie dirhema arabskiego z 821 r. na grodzisku w Lubieszewie dobrze wpisuje się w rekonstruowany przebieg tego szlaku. Ze względu na oczywiste uzupełnianie się różnych rodzajów ciągów komunikacyjnych docenić należy również możliwość wykorzystania traktu wodnego prowadzącego do Wielkopolski bezpośrednio z jeziora Lubie w dół Drawy. W przeciwieństwie do większości grodów Pojezierza Zachodniopomorskiego gros warowni w regionie naddrawskim przetrwało w głąb XI w., choć ich status polityczny - zapewne zmienny w ciągu tego stulecia - na podstawie wyników analizy źródeł archeologicznych trudny jest obecnie do określenia.

Omówiony pokrótce region należy do lepiej rozpoznanych obszarów w skali całego interioru pomorskiego. Warto jednak przyjrzeć się również innym strefom osadniczym leżącym także w strefie głównego wododziału we wschodniej części Pojezierza. Już dawno wskazywano na pograniczny charakter dwóch grodów w Starym Drawsku (Drahimiu) usytuowanych nad Jeziorem Drawskim, największym i najgłębszym akwenem omawianego obszaru (Janocha, Lachowicz i Ptaszyńska 1972, s. 12). Wprawdzie charakter starszego grodziska w Starym Drawsku datowanego na VII/VIII-VIII/IX w. (stanowisko 2) jest dość problematyczny, gdyż jak się zdaje, w okresie tym miejsce to wykorzystywano w celach osadniczych jedynie okazjonalnie (Olczak, Siuchniński 1970, s. 158), to badania wykopaliskowe przeprowadzone na drugim z obiektów przyniosły bardziej konkretne informacje dotyczące jego roli w regionie (stanowisko 1). Niestety jak dotąd nie opracowano szczegółowych wyników tych badań. Z opublikowanych wyrywkowo informacji wynika jednak, że na wyspie usytuowanej w strategicznym miejscu pomiędzy Jeziorem Drawskim a Żerdno znajdował się gród, którego początki funkcjonowania badacze tego stanowiska odnieśli nawet do schyłku VII lub początku VIII w., natomiast koniec do 1. połowy wieku XII, łącząc jego zniszczenie z ekspedycją wojenną Bolesława Krzywoustego (Janocha, Lachowicz i Ptaszyńska 1972, s. 30-31). Inaczej chronologię stanowiska widział jednakże W. Łosiński, który skłaniał się do datowania tego obiektu na IX i X wiek (Łosiński 1982, s. 252). Niestety problem uściślenia chronologii grodu nie zostanie wyjaśniony bez wyników szczegółowej analizy materiału źródłowego, zwłaszcza ceramiki naczyniowej odkrytej na tym 
stanowisku. Tym bardziej że teren zajęty pierwotnie pod budowę grodu został mocno przeobrażony w okresie późniejszym, w związku ze wzniesieniem w tym miejscu pod koniec XIV w. przez zakon rycerski Joanitów zamku. Na szczęście z wczesnego średniowiecza zachowały się fragmenty bliżej nieokreślonych konstrukcji drewnianych wału, wzmacnianych dodatkowo płaszczem kamiennym, oraz relikty naziemnej zabudowy zrębowej. Wśród ruchomego materiału zabytkowego odnotowano znaczną liczbę ceramiki naczyniowej, dużą serię kości zwierzęcych, militaria oraz liczne materialne pozostałości hutnictwa i kowalstwa. W starszych fazach wczesnego średniowiecza gród drawski stanowił jedno z ogniw systemu grodowego rozwiniętego na tych terenach w ramach wyróżnionej przez W. Łosińskiego kolejnej wspólnoty terytorialnej z IX-X w. obejmującej poza zlewnią górnej Drawy również jezioro Komorze (Sitno, Rakowo), w sumie około $300 \mathrm{~km}^{2}$. Słuszność takiego poglądu potwierdzono ostatnio w trakcie przeprowadzonych badań weryfikacyjno-sondażowych grodzisk Pojezierza Drawskiego, w wyniku których odkryto dwa nowe stanowiska tego rodzaju (Siemczyno I nad jeziorem Wilczkowo, Siemczyno II nad Jeziorem Drawskim). Nie wiadomo natomiast, czy nie należałoby wyłączyć z tej grupy obiektów grodziska w Kluczewie, związanego zapewne już z o wiele późniejszą niemiecką kolonizacją tych ziem (Nowa Marchia), a ponadto grodziska w Sikorach, gdzie w wyniku ostatnio przeprowadzonych prac weryfikacyjnych stwierdzono jedynie obecność materialnych śladów z wczesnej epoki żelaza. Jak dotąd brak jest archeologicznych świadectw na łączność omawianej struktury osadniczej z regionem usytuowanym w kolanie Drawy i jeziora Lubie. Natomiast podobnie datowana struktura terytorialna i o zbliżonej wielkości powierzchni odzwierciedlona $\mathrm{w}$ układzie przestrzennym grodzisk znajdowała się na północ od głównego wododziału pomorskiego w zlewni Dębnicy prawego dopływu Parsęty (Stare Koprzywno, Popielewo, Połczyn Zdrój i Buślary). Wprawdzie łączona ona była przez W. Łosińskiego ze zgrupowaniem łobeskim w dorzeczu środkowej i górnej Regi, jednak z danych AZP wynika, że stanowiła ona osobne skupienie oddzielone od grupy nad dolną Regą słabo zasiedloną zlewnią Mogilicy.

Większość z tych grodów leżących po obu stronach głównego wododziału została zniszczona lub opuszczona $\mathrm{w}$ ciągu $\mathrm{X}$ w., co interpretować należałoby jako efekt istotnych przeobrażeń społeczno-politycznych związanych z ekspansją piastowską. Słabo na tych terenach rysuje się również dla tego okresu kwestia kontaktów handlowych i rozwoju gospodarki towarowo-pieniężnej. Badacze przyjmują, że po wschodniej stronie jeziora wiódł szlak dalekosiężny łączący Wielkopolskę z Pomorzem, prowadzący być może z samego Czarnkowa nad Notecią (Wyrwa 2007, s. 295). Poza jednym dirhemem arabskim z 930 r. odkrytym w okolicach Popielewa i jednym nieokreślonym znanym z wyspy w Suliborzu, w strefie tej brak właściwie znalezisk monetarnych $\mathrm{z}$ pierwszych trzech dekad X w., tak bardzo charakterystycznych dla zlewni górnej Regi. Niewykluczone zatem, że rekonstruowany na tym obszarze szlak południkowy przechodzący przez gród w Starym Drawsku w kierunku Białogardu ma dużo młodszą metrykę i uruchomiony 
został dopiero pod koniec X w., czego świadectwem może być skarb srebrnego kruszcu z Połczyna Zdroju zdeponowany po 995 r. (ozdoby, monety arabskie, bizantyjskie, zachodnioeuropejskie; Horoszko i in. 2016, s. 461) oraz usytuowany nieco z boku rekonstruowanego szlaku skarb ze Słowianek (głównie monety niemieckie, po 1000 r.; Horoszko i in. 2016, s. 415).

W kontekście próby określenia genezy tego szlaku fundamentalne znaczenie mają wyniki ostatnio przeprowadzonych badań archeologicznych w Suliborzu na dawnej wyspie Jeziora Drawskiego położonej w północnej części tego akwenu. Odkryto tu bowiem pozostałości niewielkiej (0,25 ha) osady datowanej na 2 . połowę XI i XII w., o czym przekonuje przede wszystkim występowanie charakterystycznej ceramiki naczyniowej typu Vipperow i Teterow nawiązującej pod względem technologiczno-stylistycznym do materiałów $\mathrm{z}$ drugiej fazy wyspy w Żółtym. Ze względu na zaawansowany stopień niwelacji terenu trudno jednoznacznie orzec, czy osada ta była chociaż częściowo ufortyfikowana. Znaczna miąższość nawarstwień kulturowych odkryta na zachodnim stoku wyspy może wskazywać na taką ewentualność. Wydatne obniżenie poziomu wody w Jeziorze Drawskim w czasach nowożytnych spowodowało również zniszczenie ewentualnych - często spotykanych na terenie Pojezierza na stanowiskach „wyspowych” - pozostałości urządzeń wodno-komunikacyjnych. W centralnej, najbardziej wyeksponowanej części wyspy natrafiono natomiast na ślady zabudowy typu półziemiankowego. Na specjalną uwagę zasługują tu odkryte niestety poza kontekstem stratygraficznym srebrne monety, w tym fragment dirhema arabskiego, krzyżówka starszego typu (?) i denar Brzetysława czeskiego (lata 1034-1050), a ponadto domniemany odważnik wagowy, brązowa aplikacja tarczowata i srebrny paciorek, co wskazuje na istnienie w tym miejscu - podobnie jak na wyspie w Żółtym - ośrodka wymiany handlowej. Nie jest znana relacja chronologiczno-funkcjonalna osady w Suliborzu i grodu w Starym Drawsku, sądzić jednak można, że po upadku grodu osada ta - leżąca w strefie południowego pogranicza księstwa zachodniopomorskiego - stała się głównym ośrodkiem osadniczym w omawianym mezoregionie.

Kolejne struktury osadnicze w strefie pogranicza pomorsko-wielkopolskiego obejmujące tym razem zlewnię górnej Parsęty i Gwdy rozpoznano w rejonie dzisiejszego Szczecinka, w okolicach jezior Wierzchowo i Wielimie. Początki zasiedlenia tego regionu miałyby, zarówno wg W. Łosińskiego, jak i J. Olczaka i K. Siuchnińskiego sięgać VII i VIII w., kiedy to powstały pierwsze stosunkowo niewielkie $(0,05-0,3$ ha wnętrza) osiedla obronne zarejestrowane w Starym Wierzchowie, Gałowie i Godzimierzu z charakterystycznym materiałem ceramicznym reprezentowanym przez naczynia typu Sukow i Feldberg. Do tego samego horyzontu chronologicznego zaliczony został duży, około 0,5-hektarowy gród w Radaczu leżący na północnym brzegu jeziora o tej samej nazwie. Skupisko osadnicze w okolicach jezior Wierzchowo i Wielimie w postaci bardziej skrystalizowanej ukształtowało się dopiero w IX wieku. Na obszarze około $600 \mathrm{~km}^{2}$ powstaje wtedy sieć względnie regularnie rozmieszczonych grodów, do których poza obiektami 
o starszej metryce, zaliczyć można również gród w Sitnie, Jeleniu, Wilczych Laskach, Wierzchowie i dwa obiekty w Brzeźnie. Według W. Łosińskiego brak na tym terenie naczelnego grodu plemiennego stanowiącego główny ośrodek życia społeczno-politycznego i publicznego (Łosiński 1982, s. 192).

Kluczowe dla omawianego regionu wydaje się jednak wspomniane grodzisko w Radaczu leżące bezpośrednio przy głównym wododziale pomorskim, w strefie jednego ze źródlisk Gwdy, a ponadto w najbliższym sąsiedztwie źródeł Parsęty. Warto przyjrzeć się bliżej jego chronologii wzbudzającej liczne kontrowersje spotęgowane dodatkowo brakiem publikacji źródłowej. Według W. Łosińskiego gród ten datowany powinien być na VII-IX/X wiek (1982, s. 249). Nieco dłuższy okres jego funkcjonowania obejmujący nawet XI w. sugerowali natomiast J. Olczak i K. Siuchniński (1970, s. 110). Bardziej szczegółową datację zaproponował S. Bakiera (1988). Na podstawie szczegółowej analizy materiału ceramicznego oraz stratygrafii kulturowej wyróżnił on trzy jego fazy użytkowania: I - od VI/VII do 1. połowy VIII w., II - od 1. połowy/2. połowy VIII w. do połowy IX w. oraz III - od 3. ćwierci IX do początków X wieku. Tak wczesną chronologię tego stanowiska słusznie zakwestionował natomiast M. Dulinicz, który początki tego gro$\mathrm{du}$, podobnie jak cały najstarszy horyzont budownictwa grodowego na Pomorzu Środkowym, powiązał z przełomem VIII/IX w., natomiast drugą fazę najwcześniej z IX i 1. połową X wieku (Dulinicz 2001, s. 245). Świadczyć o tym mogą przede wszystkim występujące $\mathrm{w}$ najstarszych zespołach ceramiki odkrytych na grodzisku pojedyncze okazy typu Menkendorf współwystępujące z dominującymi naczyniami typu Sukov i Feldberg.

Wbrew sugestiom W. Łosińskiego dotyczącym braku głównego ośrodka plemiennego na omawianym obszarze wydaje się, że gród w Radaczu mógł taką nadrzędną względem całego regionu rolę pełnić. Przekonuje o tym nie tylko duża powierzchnia wnętrza tego obiektu, zwłaszcza na tle pozostałych grodów omawianego regionu, ale przede wszystkim inne jego cechy nawiązujące do dużych warowni z dorzecza dolnej Parsęty horyzontu Kędrzyno-Bardy. Do najważniejszych z nich zaliczyć należałoby układ zabudowy usytuowanej głównie w strefie przywałowej, liczne ślady działalności metalurgicznej, zarówno kowalstwa, jak i odlewnictwa metali kolorowych, dużą frekwencję naczyń wykonanych w technologii znamiennej dla warsztatów rzemieślniczych (bardziej zaawansowane odmiany naczyń typu Feldberg) oraz obecność pojedynczych przedmiotów luksusowych wskazujących na rozwój wymiany dalekosiężnej (m.in. dirhem arabski z 833 r. czy ostroga brązowa technotyp IIIa zapewne pochodzenia frankońskiego). Są to wszystko dość przekonywające materialne przejawy obecności kultury elitarnej świadczące o tym, że gród radacki mógł pełnić rolę czoła mezoregionalnego ugrupowania plemiennego.

Omawiany gród funkcjonował zapewne do początków lub 1. połowy X w. i zazębiał się czasowo z sąsiednim domniemanym grodem położonym również nad tym samym jeziorem zaledwie w odległości $1 \mathrm{~km}$ (Radacz, stanowisko 2). Nieste- 
ty pierwotny kształt tej warowni położonej na piaszczystym, niewielkim (do 0,25 ha) wyniesieniu wyspowym otoczonym $\mathrm{z}$ jednej strony wodami jeziora, $\mathrm{z}$ drugiej zaś bagnami jest dzisiaj trudny do odtworzenia ze względu na znaczący stopień zniszczenia grodziska. Jako unikatowy, co najmniej w skali Pomorza, uznać należy natomiast dookolny wał/groblę pierścieniowato otaczającą równinę biogeniczną i samą wyspę. Prowadził do niej drewniany most, którego szczegółowe datowanie dendrochronologiczne pozwoliło określić trzy fazy jego budowy, a pośrednio również użytkowania wyspy/domniemanego grodu: I - rok 880, II - lata 918-930, III - lata 950-968. Potencjalna synchronizacja obu obiektów warownych, przynajmniej w początkowym okresie istnienia grodu w Radaczu II w kontekście jego wyspowego położenia i unikatowego układu przestrzennego stała się podstawą do sformułowania hipotezy o jego sakralnej funkcji (Chudziak 2014, s. 50-51). Niewykluczone jednak, że po opuszczeniu lub zniszczeniu „starego” grodu w Radaczu, co nastąpiło zapewne na przełomie X/XI lub w 1. połowie X w., obiekt ten stał się głównym ośrodkiem osadniczym w tej części regionu.

Oba grody radackie leżały przy szlaku dalekosiężnym wiodącym z Wielkopolski, zapewne przez nadnotecki gród w Ujściu, w kierunku Białogardu i Kołobrzegu (Wyrwa 2006, s. 296). W przeciwieństwie do sytuacji w zlewni górnej Regi i Dębnicy brak na północ od głównego wododziału rozwiniętych struktur osadniczych pochodzących z IX-X w., co wskazywać mogłoby, że użytkowany był w tym okresie wariant wodny tego szlaku wiodący w dół Parsęty. Niewykluczone, że krzyżował się on również ze szlakiem wschodnim, przecinającym Pojezierze Krajeńskie, ziemię chełmińską i wiodącym w stronę Mazowsza i Rusi (Chudziak 1997, s. 106; również Łosiński 2002). Ostatnio odkryty w okolicach Szczecinka skarb dirhemów arabskich $\mathrm{z}$ 1. połowy $\mathrm{X}$ w. tylko potwierdza opinię o znaczeniu tego ważnego węzła komunikacyjnego. Jego ranga utrzymała się również w kolejnym stuleciu, kiedy na Jeziorze Parsęckim w obrębie niewielkiej wyspy zbudowano osiedle, którego funkcja żywo dyskutowana jest ciągle w literaturze przedmiotu. W 2. połowie XIX w. w wyniku melioracji jeziora wokół wyspy odkryto dobrze zachowane konstrukcje drewniane, które zinterpretowano jako pozostałości osiedla z zabudową palafitową (Kasiski 1869, 1879) lub naziemną, zrębową (Olczak, Siuchniński 1970, s. 103). Inną propozycję wyjaśnienia charakteru tych konstrukcji dał Hermann Hinz, który uznał je za pozostałość wału. Ze względu na wiele podobieństw ze strukturą zabudowy wyspy w Żółtym wydaje się jednak, że zabudowę wyspy w Parsęcku uznać należy w pierwszej kolejności jako osadę o drewnianych nabrzeżach zbudowanych w konstrukcji skrzyniowej powszechnie stosowanej na terenach podmokłych (Chudziak, Kaźmierczak i Niegowski 2007). $\mathrm{Na}$ podstawie analizy typologiczno-porównawczej ceramiki zdominowanej przez naczynia typu Vipperow i Teterow, a ponadto trzech dat dendro pochodzących z pobliskiego mostu łączącego wyspę z lądem (AD 1058, 1072) sądzić należy, że funkcjonowała ona głównie w 2. połowie XI w. (Chudziak, Kaźmierczak, Niegowski i Ważny 2009, s. 107-108). Na północ od wyschniętego obecnie akwenu Je- 
ziora Parsęckiego, wzdłuż wschodniego skraju doliny Parsęty znane jest zsynchronizowane $\mathrm{z}$ osadą na wyspie cmentarzysko z grobami płaskimi i kurhanowymi w obrządku inhumacji (Olczak, Siuchniński 1970, s. 91-95). Strategiczne znaczenie tego osiedla usytuowanego u źródeł Parsęty przy szlaku dalekosiężnym wiodącym w kierunku Bałtyku jest oczywiste. Znamienne jest również, że z okresu jego funkcjonowania pochodzą dwa srebrne skarby monet głównie zachodnioeuropejskich tworzące razem z nim układ liniowy odzwierciedlający przebieg tego szlaku (Stary Chwalim po 1027/40 oraz Mosina po 1055 roku). Do tej grupy depozytów włączyć należałoby również skarb z Barwic datowany po 1077 roku (Horoszko 2016, s. 474). Jedynym znanym z tego terenu grodziskiem o zbliżonej metryce jest obiekt w Ostrowąsach (X-XII w.), co wskazywać może, że lądowy trakt biegł prawą stroną Parsęty.

$\mathrm{Na}$ północ od regionu obejmującego zlewnię górnej Parsęty i górnej Gwdy wyraźnie wyodrębnia się kolejna wspólnota terytorialna o powierzchni około $700 \mathrm{~km}^{2}$ ze względnie regularnym układem grodzisk, z których większość związana jest z górną Radwią, lewym dopływem Parsęty (Głodowo, Górawino, Bobolice, Porost, Kruków, Stare Borne, Bobięcino). Stanowi ona wschodnią rubież osadnictwa zachodniopomorskiego leżącą już poza strefą pogranicza pomorsko-wielkopolskiego, stąd zasadniczo niewchodzącą w zakres niniejszego studium. Warto jednak zwrócić uwagę na dwa centra osadnicze związane ze szlakiem dalekosiężnym łączącym ten region z ziemią sławieńską i Pomorzem Gdańskim. Pierwsze z nich znajdowało się w Żydowie (Stare Borne) nad jeziorem Kwiecko w miejscu wypływu Radwi z tego akwenu. W obrębie silnie wyodrębnionego cypla w 1. połowie $\mathrm{X}$ w. zbudowano tam dwuczłonowy gród, do którego od strony północnej przez zabagnione tereny doliny Radwi prowadziła moszczona drewnem droga i przeprawa mostowa. Na podstawie badań dendrochronologicznych ustalono dwa etapy budowy tego traktu przypadające na lata 936-940 oraz 955/956 (Chudziak, Kaźmierczak, Niegowski i Ważny 2009, s. 115). Pojedyncza data ścięcia pala pochodząca z około $910 \mathrm{r}$. wskazuje na możliwość wcześniejszej metryki tej przeprawy. $\mathrm{Z}$ tego okresu odkryto również ślady zabudowy w obrębie samego grodu, generalnie niewykazującego jednak śladów intensywnego użytkowania (bliżej nieokreślone pod względem funkcji konstrukcje kamienne z ceramiką typu Menkendorf). Warownia ta funkcjonowała zapewne również pod koniec X i w 1. połowie XI w., o czym świadczyć mogą relikty drewnianej zabudowy naziemnej pochodzące z młodszej fazy tego obiektu. Pozostałością drugiego ośrodka o ewidentnie pogranicznym charakterze jest dwuczłonowe grodzisko w Bobięcinie na wyspie Jeziora Bobięcińskiego oraz usytuowane w odległości kilkuset metrów od niego na brzegu tego samego akwenu, grodzisko w Świerczewie. Genezę pierwszego z nich wiązać należy z IX-X w., kiedy na skraju wyspy wybudowano niewielki (do 0,07 ha powierzchni) gródek zapewne o charakterze strażniczym. Przylegająca doń duża warownia obejmująca znaczną część wyspy (ponad 1 ha) powstała tu zapewne dopiero w XI wieku. Z tego okresu pochodzą relikty mostu prowadzącego do 
grodu, które dzięki badaniom dendrochronologicznym określić można na lata 1017/1018 oraz 1080-1082/1083 (Chudziak, Kaźmierczak, Niegowski i Ważny 2009, s. 102). Podobnie datować należy grodzisko w Świerczewie, którego funkcja z uwagi na brak nawarstwień kulturowych wewnątrz zachowanych obwałowań jest trudna do określenia. Odkrycie licznych militariów na dnie Jeziora Bobięcińskiego w najbliższym sąsiedztwie wyspy grodowej wskazuje na jej wyjątkowe znaczenie strategiczne na pograniczu zachodniopomorsko-sławieńskim (Spors 1973, s. 61-62).

Analiza struktur osadniczych omawianej części Pojezierza Zachodniopomorskiego obejmującego tereny moreny czołowej przeprowadzona pod kątem kształtowania się pogranicza pomorsko-wielkopolskiego w VIII-XI w. skłania do wyróżnienia kilku etapów jego rozwoju:

\section{- etap 1 (VIII - lata 80.-90. IX wieku)}

Zgodzić się należy częściowo z opinią W. Łosińskiego dotyczącą istnienia na terenie Pojezierza organizmu politycznego o dość archaicznych formach ustrojowych przejawiających się, przynajmniej początkowo, we względnej niezależności wspólnot skupionych głównie wokół ośrodków grodowych (VIII w., dorzecza górnej Drawy, górnej Gwdy i Radwi). Wydaje się jednak, że stan ten uległ radykalnej zmianie w momencie budowy usytuowanego niedaleko źródeł Parsęty grodu w Radaczu I, co nastąpiło zapewne w 2. połowie VIII w., a niewykluczone, że dopiero pod koniec tego stulecia, jak proponował M. Dulinicz. Gród ten funkcjonujący co najmniej do schyłku IX lub nawet początku X w. posiadał wszelkie cechy centrum polityczno-gospodarczego z rozwiniętym rzemiosłem i handlem, co pozwala łączyć go z młodszym horyzontem najstarszych ośrodków obronnych nad dolną Parsętą określanych zazwyczaj jako grody typu Feldberg/Kędrzyno. Ze względu na ponadprzeciętną wielkość i nieagrarne funkcje upatrywać należy nadrzędnej roli tego ośrodka w strukturze lokalnej wspólnoty plemiennej obejmującej górne dorzecze Gwdy. W tym okresie użytkowano zapewne szlak wodny wzdłuż Parsęty łączący gród radacki z Białogardem (4-5 faza grodu, wg Cnotliwy) oraz z leżącym dalej na północ czołem plemiennym w Bardach. Odwołując się do teorii komunikacji, gród ten należy uznać jako gateway city - „miasto-wrota” powstałe w wyniku penetracji osadniczej prowadzonej w górę Parsęty (Burghardt 1971). Ośrodki takie kształtują się w strefie kontaktowej pomiędzy różnymi homogenicznie obszarami, służąc jako zwornik łączący różne strefy fizjograficzne, jak również gospodarcze i polityczne (Chudziak, Siemianowska 2017, s. 295). Budowa grodu w Radaczu I może wskazywać zatem na integrację terytorialną tych ziem z dorzeczem dolnej Parsęty i włączeniem ich w nurt dalekosiężnej wymiany rozwijającej się w nadbałtyckiej strefie gospodarczej (Leciejewicz 1992; Łosiński 2008, s. 75). Szczególne znaczenie w tym kontekście miał zapewne gród w Białogardzie zlokalizowany na obszarze o ,starych” tradycjach osadniczych sięgających schyłku starożytności (Machajewski 2017, s. 283). Poza tą strefą pozostawały natomiast zapewne pojedyncze ośrodki nad górną Drawą niewykazujące wyraźnych śladów kontaktów 
kulturowych z dorzeczem Parsęty, ani tym bardziej z Wielkopolską. Słabo zasiedlone pozostawały również tereny dorzecza górnej Regi, skolonizowane zasadniczo w kolejnych dwóch stuleciach.

\section{- etap 2 (lata 80.-90. IX - lata 60.-70. X wieku)}

W ostatniej dekadzie IX w. w strukturze osadnictwa środkowopomorskiego dokonały się zasadnicze zmiany polegające na zaniku dużych i średnich warowni i rozpowszechnieniu się nowej formy silnie ufortyfikowanych małych obiektów obronnych typu Świelubie (Łosiński 1982, s. 194-195). Ze zjawiskiem tym wiązać należy genezę większości grodów omawianej części Pojezierza, datowanych z reguły w szerokim przedziale czasu na IX-X wiek. Tworzyły one regularne układy przestrzenne odzwierciedlające, jak zakładamy, centra wspólnot terytorialnych obejmujących szeroki pas pojezierny po obu stronach głównego wododziału pomorskiego, co świadczyłoby o integracji społeczności zamieszkujących te dwie strefy. W tym nurcie przeobrażeń struktury osadniczej pozostaje zapewne również opuszczenie grodu w Radaczu I i wzniesienie nieopodal małej warowni w Radaczu II (lata 874-880), choć wielce prawdopodobna jest częściowa koegzystencja obu tych miejsc centralnych. Bezpośrednio przy jednej z nowych warowni usytuowanej u źródeł Starej Regi na wyspie Jeziora Zarańskiego około 890 r. założono osiedle pełniące złożone funkcje społeczno-gospodarcze realizowane głównie w sferze sacrum i wymiany handlowej (Żółte). Nie jest wykluczone, że przy budowie tego ośrodka wykorzystano wzorce północno-zachodnioeuropejskie, co widoczne jest w zastosowaniu idei charakterystycznej dla iryjskich osiedli typu crannog. Ze względu na jego znamienne położenie przyrodniczo-kulturowe kluczowe dla komunikacji dalekosiężnej ośrodek ten określić można, podobnie jak dla wcześniejszego etapu osadnictwa gród radacki jako gateway city. Jest to jedyny znany jak dotąd tego rodzaju ośrodek w strefie Pojezierza datowany na omawiany okres, co wobec dużego nagromadzenia srebrnego kruszcu pochodzenia arabskiego w najbliższym regionie wskazywałoby na uruchomienie wzdłuż Starej Regi szlaku dalekosiężnego łączącego wybrzeża Bałtyku i górnej Drawy (do Kołobrzegu via Białogard $)^{14}$. To z tego regionu, podobnie jak z Wolina, już w latach 30 . X w. srebro mogło być transferowane w kierunku Wielkopolski, gdzie kształtowały się zręby organizacyjne państwa Piastów (Kara 2009, s. 310-311). Niewykluczone, że transfer srebra odbywał się również wzdłuż szlaku Parsęta-Gwda, o czym świadczyć może niedawno odkryty wstępnie datowany na ten okres skarb w Szczecin$\mathrm{ku}^{15}$. Znamienna jest koincydencja czasowa powstania dookolnych umocnień wyspy w Żółtym (lata 886-890 oraz 900 r.), mostu prowadzącego do grodu w Radaczu II (880 r.) oraz najstarszych konstrukcji grodu w Kołobrzegu (po 878-879 r.; Lecie-

\footnotetext{
14 Odgałęzieniem tego szlaku była droga w kierunku Kamienia Pomorskiego, która, z tej perspektywy patrząc, zasługuje na osobne opracowanie.

15 Podziękowania dla D. Malarczyk za informację o chronologii tego skarbu.
} 
jewicz, Rębkowski 2007, s. 307), jak również przebudowy grodu w Białogardzie (6 faza, lata 878-892, 902/903; Cnotliwy 2005). Jesteśmy skłonni ten fakt uznać za przesłankę do wnioskowania o integracji społeczno-gospodarczej i politycznej Pomorza Środkowego przejawiającego się w politycznym scaleniu dorzecza Parsęty i Regi sięgającym po źródła obu tych rzek. Trudno natomiast orzec, czy w zasięgu wpływów omawianego organizmu politycznego pozostawały również wspólnoty rozwijające się na terenach dorzecza górnej Drawy, oddzielone od skupiska nadreskiego szerokim pasem puszcz określonym w dokumencie Warcisława z 1254 jako dessertum... Sarcthicze circa Draunam fluvium (Wielgosz 2006a, S. 313).

\section{- 3 etap (lata 60./70. X - lata 40. XI wieku)}

Najpewniej w 2. połowie X w. większość grodów Pojezierza o genezie plemiennej przestała istnieć, co wiązane jest na ogół z ekspansją militarną Piastów (Łosiński 1983). Większa skala zniszczeń dotknęła zapewne region jezior Wierzchowo i Wielimie oraz górnej Radwi, gdzie należy liczyć się ze znaczącą depopulacją tego regionu (np. gród w Starym Bornym zniszczony po 955/956 roku). Nieco lepiej sytuacja wyglądała w dorzeczu górnej Drawy, gdzie część ośrodków grodowych położonych zwłaszcza na południe od głównego wododziału przetrwała, co mogło mieć związek ze strategicznym znaczeniem tego regionu w trakcie ekspansji Piastów w kierunku Bałtyku. Z tym etapem podboju omawianego regionu wiązać należy zniszczenie ośrodka w Żółtym (zarówno grodu, jak i osiedla obronnego na wyspie), w Radaczu (po 971/972 roku?) oraz być może zaadaptowanie przez państwo gnieźnieńskie grodu w Nętnie (około lat 963-975), stanowiącego - biorąc pod uwagę zestaw występujących tam przedmiotów luksusowych i ich kontekst kulturowy - wielkopolski przyczółek władzy państwowej w tej strefie. Przejęcie tego ośrodka przez Piastów stanowiłoby znakomity punkt wyjścia do podboju ziem leżących w dorzeczu środkowej i dolnej Parsęty, w tym przede wszystkim do opanowania centrów osadniczych w Białogardzie i Kołobrzegu. Przypuszcza się, że przebudowa tego grodu związana z umacnianiem władzy księcia polskiego nastąpiła dopiero po 979, a najpewniej po 986 roku (Leciejewicz, Rębkowski 2007, s. 308). Niewykluczone, że podobne znaczenie pełnił gród w Drahimiu/Starym Drawsku I leżący nad Jeziorem Drawskim. Możliwe jest w tym przypadku uruchomienie kolejnego w omawianej strefie szlaku łączącego Pomorze z Wielkopolską, czego świadectwem mogą być depozyty monet zachodnioeuropejskich datowane po 995 i 1000 r. odkryte niedaleko Drahimia/Starego Drawska. Miałby on zatem młodszą metrykę w stosunku do „starych” szlaków prowadzących wzdłuż Parsęty i Regi.

\section{- 4 etap (lata 40. XI-XI/XII wiek)}

Wszystkie trzy połączenia dalekosiężne prowadzące w kierunku Białogardu i dalej Kołobrzegu funkcjonowały natomiast od lat 40. XI wieku. Świadectwem 
ich istnienia są trzy ośrodki wyspowe leżące niemal w równym od siebie oddaleniu: Żółte na Jeziorze Zarańskim u źródeł Regi (lata 1042-1082), Sulibórz na Jeziorze Drawskim niedaleko źródeł Drawy i Parsęcko na Jeziorze Parsęckim u źródeł Parsęty (lata 1058, 1072). Ostatni z wymienionych punktów osadniczych przejmuje $\mathrm{w}$ regionie rolę przypisaną wcześniej młodszemu grodowi w Radaczu. Niewykluczone, że w tym samym układzie liniowym widzieć należałoby leżące już na Pojezierzu Bytowskim grodzisko w Bobięcinie (lata 1017/1018-1080), a być może, że również grodzisko w Grąbczynie na jeziorem Wierzchowo. Rewitalizacja wyspy w Żółtym świadczyłaby o nawiązaniu do wcześniejszej idei dotyczącej kształtowania się pogranicza plemiennego. Wszystkie te punkty zdają się zatem wyznaczać południową i południowo-wschodnią granicę księstwa zachodniopomorskiego ze stolicą w Kołobrzegu, które w początku omawianego okresu łączyć można z księciem Zemuzilem. Z tym, że pierwsze trzy (Żółte-Sulibórz-Parsęcko) wyznaczałyby pogranicze $z$ Wielkopolską, natomiast Bobięcino i ewentualnie Grąbczyn z księstwem sławieńskim. Zgodnie z modelem systemu komunikacyjnego stworzonego na potrzeby badań nad rozwojem transportu we współczesnych krajach nierozwiniętych, liczyć należy się dla omawianego okresu z powstaniem połączenia wewnętrznego, traktów lądowych, łączącego wszystkie te ośrodki (Taafe, Morill i Gould 1963). Liczne znaleziska monetarne pochodzące z tych pogranicznych wysp oraz występujące $w$ ich najbliższym sąsiedztwie skarby srebrnego krusz$\mathrm{cu}$ świadczą także o rozwiniętej w tym okresie gospodarce towarowo-pieniężnej i stworzeniu scentralizowanej struktury politycznej. Niewykluczone jest również, że przeciwwagą zachodniopomorskich ośrodków wyspowych były w 2 . połowie XI w., przynajmniej początkowo, podporządkowane zapewne Wielkopolsce grody nad Drawą: Drawsko Pomorskie oraz Stare Drawsko, a ponadto nowo zbudowana w tym okresie warownia w Złocieńcu. Ze względu na brak odpowiednich przekazów pisanych można się jedynie domyślać, że pogranicze to $\mathrm{z}$ czasem przestało jednak pełnić swoją rolę $\mathrm{w}$ wyniku ekspansji książąt pomorskich na tereny nadnoteckie. Powrót do sytuacji terytorialno-politycznej z połowy XI w. nastąpić mógł dopiero po podbojach Bolesława Krzywoustego korzystającego z pewnością ze starych szlaków w swoim marszu na Białogard i Kołobrzeg.

\section{LITERATURA}

Behla R. 1888, Die vorgeschichtlichen Ründwalle im östlichen Deutschland, Berlin.

Brzostowicz M. 2007, Wielkopolska pótnocna w czasach przedpiastowskich, w: Pradolina Noteci na tle pradziejowych $i$ wczesnośredniowiecznych szlaków handlowych, red. H. Machajewski, J. Rola, Poznań, s. 269-280.

Burghardt A. F. 1971, A hypothesis about gateway cities, Annals of the Association of American Geographers, t. 61, s. 269-285.

Chudziak W. 1997, Dalekosiężne szlaki komunikacyjne w strefie chetmińsko-dobrzyńskiej w X-XI wieku, w: Benedyktyńska praca. Studia historyczne ofiarowane o. Pawłowi Sczanieckiemu w 80. rocznice urodzin, red. O.J.A. Spież, Z. Wielgosz, Kraków, s. 101-118. 
- 2006, Wczesnośredniowieczny grot włóczni z Nętna - przyczynek do studiów nad chrystianizacja Pomorza Środkowego, w: Świat Stowian wczesnego średniowiecza, red. M. Dworaczyk, A.B. Kowalska, S. Moździoch, M. Rębkowski, Szczecin, s. 647-655.

- 2009, Wyspa w Żóttym na Jeziorze Zarańskim - na pograniczu rzeczywistości i transcendencji, w: Studia nad dawna Polska, t. 2, Materiały z wykładów wygłoszonych w Muzeum Początków Państwa Polskiego w Gnieźnie od października 2008 do czerwca 2009 roku, „Biblioteka Muzeum Początków Państwa Polskiego" 3, red. T. Sawicki, Gniezno, s. 47-70.

- 2014, Z badań nad funkcja matych i średnich warowni na obszarze Pomorza, w: Funkcje grodów w państwach wczesnośredniowiecznej Europy Środkowej. Społeczeństwo, gospodarka, ideologia, red. K. Chrzan, K. Czapla, S. Moździoch, Wrocław, s. 43-59.

Chudziak W., Kaźmierczak R. (ed.) 2014, The Island in Żółte on Lake Zarańsko - Early Medieval Gateway into West Pomerania, Torun.

- 2017, Wyspa w Żóttym na Jeziorze Zarańskim w okresie wczesnego średniowiecza - „brama” do Pomorza Zachodniego, w: Pradoliny pomorskich rzek. Kontakty kulturowe i handlowe spoleczeństw w pradziejach i wczesnym średniowieczu, red. M. Fudziński, W. Świętosławski, W. Chudziak, Gdańsk, s. 327-340.

Chudziak W., Kaźmierczak R., Niegowski J. 2007, Próba reinterpretacji zabudowy wyspy w Parsęcku na Pomorzu Środkowym, „Przegląd Archeologiczny” t. 55, s. 168-170.

- 2009, Z badań nad wczesnośredniowiecznym zespotem osadniczym w Starym Bornem na Pomorzu Środkowym, w: Acta Archaeologica Pomoranica, t. 3, XVI Sesja Pomorzoznawcza. Szczecin 22-24 listopada 2007 r., cz. 1. Od epoki kamienia do okresu wczesnośredniowiecznego, red. A. Janowski, K. Kowalski, S. Słowiński, Szczecin, s. 383-394.

- 2011, Podwodne dziedzictwo archeologiczne Polski. Katalog stanowisk (badania 2006-2009), Torun.

- 2016, Podwodne dziedzictwo archeologiczne Polski. Katalog stanowisk (badania 2011-2015), Torun.

Chudziak W., Kaźmierczak R., Niegowski J., Ważny T. 2009, Ze studiów nad genezq wczesnośredniowiecznych mostów na obszarze Pomorza, „Przegląd Archeologiczny”, t. 57, s. 99-129.

Chudziak W., Siemianowska E. 2014, Żółte settlement centre against the Pomeranian background, w: The Island in Żółte on Lake Zarańsko - Early Medieval Gateway into West Pomerania, (ed.) W. Chudziak, R. Kaźmierczak, Torun, s. 425-440.

- 2016, Problem przyłaczenia Pomorza Środkowego do państwa pierwszych Piastów. Gtos archeologa, w: Tradycje i nowoczesność. Początki państwa polskiego na tle środkowoeuropejskim w badaniach interdyscyplinarnych, (red.) H. Kočka-Krenz, M. Matla, M. Danielewski, Poznań, s. 187-206.

- 2017, Z badań nad systemem komunikacji we wczesnym średniowieczu, w: Pradoliny pomorskich rzek. Kontakty kulturowe $i$ handlowe społeczeństw w pradziejach $i$ wczesnym średniowieczu, red. M. Fudziński, W. Świętosławski, W. Chudziak, Gdańsk, s. 327-340.

Chudziak W., Hildebrandt T., Kaźmierczak R. 2011, Wyniki badań archeologicznych na stanowisku 2 w Radaczu w latach 2008-2009, w: XVII Sesja Pomorzoznawcza, t. 1. Od epoki kamienia do wczesnego średniowiecza, (red.) M. Fudziński, H. Paner, Gdańsk, s. 665-674.

Cnotliwy E. 2005, Pierwsze dendrodaty z białogardzkiego grodziska, „Folia Praehistorica Posnaniensia”, t. $13 / 14$, s. $271-278$.

Dulinicz M. 2001, Kształtowanie się Słowiańszczyzny Północno-Zachodniej. Studium archeologiczne, Warszawa.

Eggers H. J. 1960, Die wendischen Burgwälle in Mittelpommern, „Baltische Studien, Neue Folge“, t. 47, s. 13-47.

Horoszko G., Piniński J., Ilisch P., Malarczyk D., Nowakiewicz T. 2016, Frühmittelalterliche Münzfunde aus Pommern, w: Frühmittelalterliche Münzfunde aus Polen. Inventar II, red. M. Bogucki, P. Ilisch, S. Suchodolski, Warszawa.

Janocha H., 1964, Badania archeologiczno-architektoniczne na zamku w Starym Drawsku (Drahimiu) pow. Szczecinek w 1963 r., „Materiały Zachodniopomorskie”, t. 9.

- 1967, Badania archeologiczno-architektoniczne na grodzisku wczesnośredniowiecznym i zamku średniowiecznym w Starym Drawsku (Drahimiu) na stan. 1 w 1964/65 r., „Materiały Zachodniopomorskie”, t. 11.

Janocha H., Lachowicz F.J., Ptaszyńska D. 1972, Gród i zamek w Starym Drawsku, Koszalin.

Gackowski J. 1993, Historia i stan badań osad „palowych” na Pomorzu, AUNC, t. 21, s. 69-85. 
Gackowski J., Jabłoński Z. 1993, Sprawozdanie z badań archeologicznych przeprowadzonych w 1987 roku na wczesnośredniowiecznej osadzie „palowej” w Parsęcku, gm. Szczecinek (stanowisko 2), AUNC, t. 21, s. 115-133

Kara M 2009, Najstarsze państwo Piastów - rezultat przełomu czy kontynuacji? Studium archeologiczne, Poznań.

Kasiski F. W. 1869, Die Pfahlbauten in dem ehemaligen Parsantizig-See bei Neustettin, „Baltische Studien“, t. 23.

- 1874, Bericht über die Untersuchungen von Alterthümer in den Jahren 1869/1870 in dem Neustettiner von Schlochauer Kreise, „Baltische Studien“, t. 25, z. 1

Kaźmierczak R., Kowalewska B., Niegowski J. 2011, Wyniki badań archeologicznych na stanowiskach w Bobięcinie (st. 30 Świerczewie [st. 1] w latach 2008-2009, w: XVII Sesja Pomorzoznawcza, t. 1. Od epoki kamienia do wczesnego średniowiecza, red. M. Fudziński, H. Paner, Gdańsk, s. 463-470.

Kaźmierczak R., Niegowski J., Ważny T. 2006, Wczesnośredniowieczny most z Nętna na Pomorzu Środkowym, w: Stan i potrzeby badań nad wczesnym średniowieczem w Polsce - 15 lat później, red. W. Chudziak, S. Moździoch, Toruń, s. 455-463.

Kola A., Wilke G. 2004, Podwodna lokalizacja mostu przy wczesnośredniowiecznym grodzisku w Nętnie, woj. zachodniopomorskie, w: Archaeologia et historia urbana (red.) R. Czaja, G. Nawrolska, M. Rębkowski, J. Tandecki, Elbląg, s. 545-551.

2006, Wczesnośredniowieczne mosty na ziemiach polskich - stan i potrzeby badań, w: Stan i potrzeby badań nad wczesnym średniowieczem w Polsce - 15 lat później, (red.) W. Chudziak, S. Moździoch, Toruń, s. 151-173

Kowalewska B., Chudziak W., Kaźmierczak R. 2013, Badania weryfikacyjno-sondażowe wczesnośredniowiecznego zespolu osadniczego w Bobięcinie, gm. Miastko (badania 2011 rok), w: XVIII Sesja Pomorzoznawcza, t 1. Od epoki kamienia do wczesnego średniowiecza. Materiały z konferencji 16-18 listopada 2011, red. E. Fudzińska, Malbork, s. 257-270.

Kuczkowski A. 2017, Nowe wczesnośredniowieczne stanowiska archeologiczne w rejonie Siemczyna, „Zeszyty Siemczyńsko-Henrykowskie”, t. 9, s. 197-204

Kulesza W. 2015, Interdisciplinary research at the early medieval site of Żółte in Poland, Skyllis, H. 2, s. $161-171$

Kunkel O. 1932, Burgwallforschung in Pommern, Pommersche Heimatpflege, t. 3, z. 3, s. 61-92.

Kurnatowska Z. 2000, Wielkopolska w X wieku i formowanie się państwa polskiego w: Ziemie polskie $w X$ wieku i ich znaczenie $w$ ksztaltowaniu się nowej mapy Europy, red. H. Samsonowicz, Kraków, s. $99-117$.

Labuda G. 2001, Zamierzenie organizacji diecezjalnej na Pomorzu w roku 1123 (przed misja chrystianizacyjna biskupa Ottona z Bambergu), w: Instantia est mater doctrinae, Szczecin, s. 327-340.

Lachowicz F., Olczak J., Siuchniński K. 1977, Osadnictwo wczesnośredniowieczne na Pobrzeżu i Pojezierzu Wschodniopomorskim. Wybrane obszary próbne, Poznań.

Leciejewicz L., 1957, Z badań nad ksztaltowaniem się ośrodków grodowych na pograniczu pomorsko-wielkopolskim we wczesnym średniowieczu, „Slavia Antiqua”, t. 6, s. 134-171.

- 1992, Rola mniejszych rzek $w$ dziejach dawnych społeczeństw na przyktadzie Parsęty, w: Rzeki. Kultura - cywilizacja - historia, t. 1, red. J. Kułtyniak, Katowice, s. 121-140.

Leciejewicz L., Rębkowski M., 2007, Kołobrzeg. Wczesne miasto nad Battykiem, Warszawa.

Łęga W. 1930, Kultura Pomorza we wczesnym średniowieczu na podstawie wykopalisk, Toruń.

Łosiński W. 1982, Osadnictwo plemienne Pomorza (VI-X wiek), Wrocław.

- 1983, Struktura terytorialno-polityczna Pomorza w XI stuleciu w świetle archeologii, „Slavia Antiqua", t. 28, s. 113-125.

- 2002, W sprawie „wschodniej drogi” dopływu monet arabskich do Wielkopolski w X wieku, w: Moneta Mediaevalis. Studia numizmatyczne i historyczne ofiarowane profesorowi Stanistawowi Suchodolskiemu w 65. rocznicę urodzin, (red.) R. Kiersnowski, S.K. Kuczyński, M. Męclewska, M. Mielczarek, B. Paszkiewicz, Warszawa, s. 185-192.

- 2008, Archeologia ostatniego pótwiecza o wczesnym średniowieczu Pomorza Zachodniego. Dokonania - koncepcje - interpretacje, w: Pomorze Zachodnie we wczesnym średniowieczu. Studia archeologiczne, Poznań. 
- 2008a, Osadnictwo plemienne w dorzeczu Parsęty we wczesnym średniowieczu, w: Pomorze Zachodnie we wczesnym średniowieczu. Studia archeologiczne, Poznań, s. 63-79.

Łosiński W., Olczak J., Siuchniński K. 1971, Źródła archeologiczne do studiów nad wczesnośredniowiecznym osadnictwem grodowym na terenie województwa koszalińskiego, t. 4, Poznań.

Machajewski H. 2017, Pradolina środkowej Parsęty u schyłku starożytności i na początku wczesnego średniowiecza (II/III w.-VII/VIII w. n.e.), w: Pradoliny pomorskich rzek. Kontakty kulturowe i handlowe społeczeństw $w$ pradziejach $i$ wczesnym średniowieczu, (red.) M. Fudziński, W. Świętosławski, W. Chudziak, Gdańsk, s. 273-292.

Menotti F. 2012, Wetland Archaeology and Beyond. Theory and Practice, Oxford.

Naumowiczówna E. 1963, Ujście nad Notecia - gród na pograniczu wielkopolsko-pomorskim, „Fontes Archaeologici Posnanienses", t. 14, s. 212-217.

Olczak J. 1991, Formy osadnictwa na Pojezierzu Zachodniopomorskim we wczesnym średniowieczu (na podstawie źródel archeologicznych), Toruń.

Olczak J., Siuchniński K. 1966, Źródła archeologiczne do studiów nad wczesnośredniowiecznym osadnictwem grodowym na terenie województwa koszalińskiego, t. 1, Poznań.

- 1968, Źródła archeologiczne do studiów nad wczesnośredniowiecznym osadnictwem grodowym na terenie województwa koszalińskiego, t. 2, Poznań.

- 1969, Źródta archeologiczne do studiów nad wczesnośredniowiecznym osadnictwem grodowym na terenie województwa koszalińskiego, t. 3, Poznań.

Piskorski J.M. 2002, Pomorze plemienne. Historia - archeologia - językoznawstwo, Poznań.

Radka K., 2010, Podwodne badania rekonesansowe przeprowadzone przez zakład Archeologii Podwodnej w akwenach śródlądowych Polski w latach 2005-2006, AUNC, t. 31, s. 205-222.

Rębkowski M. 2007, Chrystianizacja Pomorza zachodniego. Studium archeologiczne, Szczecin.

Rosik S. 2010, Conversio gentis Pomeranorum. Studium świadectwa o wydarzeniu (XII wiek), Wrocław.

Rymar E. 1988, Jeszcze w sprawie pogranicza wielkopolsko-pomorskiego między Gwdą a Myśla w XII i XIII wieku, „Przegląd Zachodniopomorski”, 32, z. 1-2, s. 367.

- 2015, Historia polityczna i społeczna Nowej Marchii w średniowieczu (do roku 1535), Gorzów Wielkopolski.

- 2017, Drawa jako rzeka graniczna w XIII-XIV wieku, w: Z. Mieczkowski, Rzeka Drawa i 100-lecie elektrowni wodnej w Borowie, Kalisz Pomorski, s. 32-41.

Spors J. 1973, Dzieje polityczne ziem sławieńskiej, słupskiej i białogardzkiej XII-XIV w., Słupsk.

- 1986, Przynależność administracyjna ziem nad środkowa Odra i dolna Warta (ziem cedyńskiej, kinieckiej i kostrzyńskiej) w XII i I połowie XIII w., Śląski Kwartalnik Historyczny „Sobótka”, z. 1, s. 1-29.

- 1988, Studia nad wczesnośredniowiecznymi dziejami Pomorza Zachodniego. XII-pierwsza połowa XIII w., Stupsk.

Stafiński A. 1960, Najdawniejsze słowiańskie osiedla obronne w okolicach Szczecinka, „Materiały Zachodniopomorskie", t. 6, s. 209-240.

Szulta W. 2007, Wczesnośredniowieczny most w Nętnie, powiat Drawsko Pomorskie, w: XV Sesja Pomorzoznawcza. Materiaty z konferencji 30 listopada-02 grudnia 2005, red. G. Nawrolska, Elbląg, s. 285-291.

- 2008, Przeprawy mostowe na ziemiach polskich $w$ średniowieczu, Toruń.

Ślaski K. 1954, Granica wielkopolsko-pomorska w okresie wczesnego feudalizmu, „Przegląd Zachodni”, t. 10, z. 1-2, s. 91-109.

- 1960, Podziaty terytorialne Pomorza w XII-XIII wieku, Poznań.

- 1972, Z wczesnych dziejów regionu nadnoteckiego, ,Rocznik Nadnotecki”, t. 4, s. 5-14.

Śliwiński B. 2000, Pomorze w polityce i strukturze państwa wczesnopiastowskiego (X-XII w.), „Kwartalnik Historyczny", t. 57, s. 3-40.

Taafe E.J., Morill R.L., Gould P.R. 1963, Transport expansion in underdeveloped countries: a comparative analysis, „Geographical Review”, t. 53, s. 503-529.

Wielgosz Z. 2006, Pogranicze wielkopolsko-zachodniopomorskie we wczesnym średniowieczu. Krajobraz naturalny i struktury osadnicze, Poznań. 
- 2006a, Pogranicze wielkopolsko-pomorskie we wczesnym średniowieczu, w: Pradolina Noteci na tle pradziejowych $i$ wczesnośredniowiecznych szlaków handlowych, red. H. Machajewski, J. Rola, Poznań, s. 307-327.

Wilke G. 1963, Badania weryfikacyjne osiedli obronnych na terenie województwa koszalińskiego, „Z Otchłani Wieków", t. 29, z. 3, s. 172-176.

- 1985, Most wczesnośredniowieczny z Bobęcina koło Miastka. Wstępne wyniki archeologicznych badań podwodnych $i$ analiz dendrochronologicznych jego reliktów, AUNC, Archeologia 11, Archeologia podwodna 2, s. 3-26.

Wyrwa A.M., 2004, Wczesnośredniowieczne grody „, limesu” nadnoteckiego. Zarys problemu, w: Ziemia nadnotecka. Wczoraj, dziś, jutro. Materiaty z sesji naukowej odbytej w dniu 30 maja 2003 roku z okazji nadania Gimnazjum w Drawsku imienia ,,Ziemi Nadnoteckiej” (red.) A.M. Wyrwa, W. Gapski, Drawsko.

- 2006, Czynniki zwiąane z procesem formowania się grodów limesu nadnoteckiego we wczesnym średniowieczu. Stan i perspektywy badań, w: Pradolina Noteci na tle pradziejowych $i$ wczesnośredniowiecznych szlaków handlowych, red. H. Machajewski, J. Rola, Poznań, s. 281-305. 